smI Center for Sensory-Motor Interaction

Novel Mechanical Stimulation of Deep and Superficial Musculoskeletal Tissue for Enhanced Understanding of Pressure-Pain Sensitivity Mechanisms

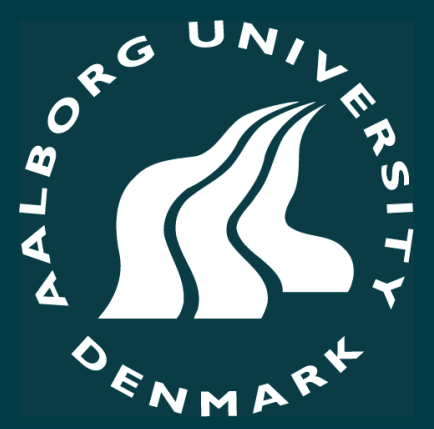

$\mathrm{PhD}$ Thesis by

Djordje Adnadjevic 
Novel Mechanical Stimulation of Deep and Superficial Musculoskeletal Tissue for Enhanced Understanding of Pressure-Pain Sensitivity Mechanisms 



\section{Novel Mechanical Stimulation of Deep and Superficial Musculoskeletal Tissue for Enhanced Understanding of Pressure-Pain Sensitivity Mechanisms}

PhD Thesis by

Djordje Adnadjevic

Center for Sensory-Motor Interaction, Department of Health Science and Technology, Aalborg University, Denmark 
ISBN 978-87-93237-39-1 (Paperback)

ISBN 978-87-93237-38-4 (Ebook)

Published, sold and distributed by:

River Publishers

Niels Jernes Vej 10

9220 Aalborg Ø

Denmark

Tel.: +45369953197

www.riverpublishers.com

Copyright for this work belongs to the author, River Publishers have the sole right to distribute this work commercially.

All rights reserved (C) 2014 Djordje Adnadjevic.

No part of this work may be reproduced, stored in a retrieval system, or transmitted in any form or by any means, electronic, mechanical, photocopying, microfilming, recording or otherwise, without prior written permission from the Publisher. 


\section{List of Abbreviations}

$\begin{array}{ll}\text { TS } & \text { Technical Study } \\ \text { QST } & \text { Quantitative Sensory Testing } \\ \text { VAS } & \text { Visual Analogue Scale } \\ \text { PPT } & \text { Pressure Pain Threshold } \\ \text { BA } & \text { Biaxial Algometer } \\ \text { NGF } & \text { Nerve Growth Factor }\end{array}$




\section{TABLE OF CONTENTS}

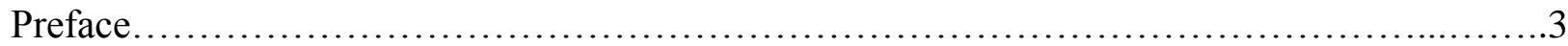

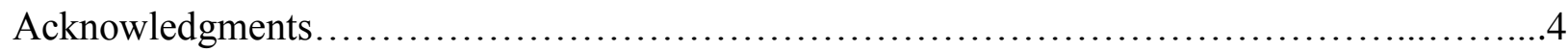

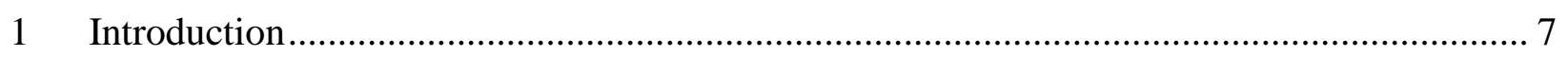

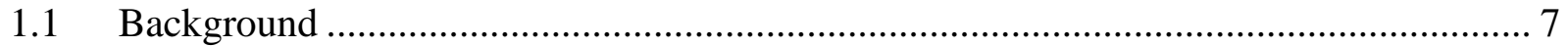

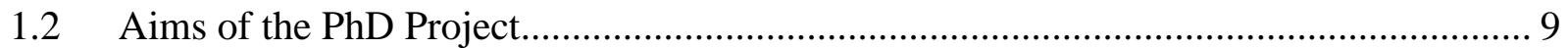

2 Mechanisms of pressure-pain and principles of pain measurement ……………................ 11

2.1 Basic traits of muscle mechano-nociception ................................................................ 11

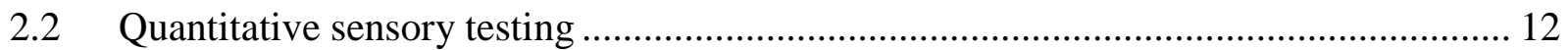

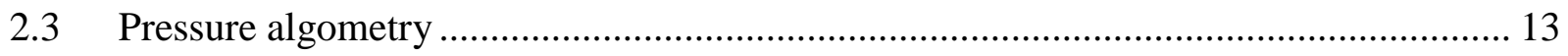

2.3.1 Single point pressure algometry - unidirectional stimulation ................................ 13



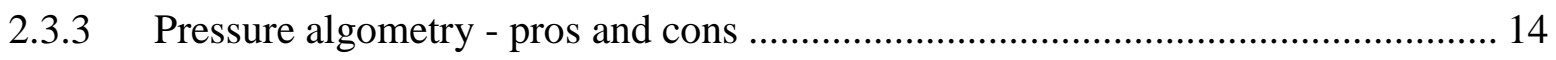

3 Biaxial pressure algometry - bidirectional stimulation .......................................................... 16

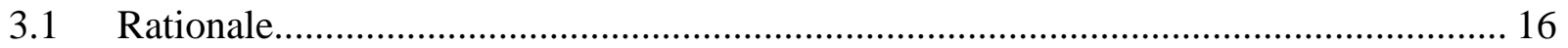

3.2 Stimulation setup............................................................................................ 18

3.3 Pain response measurement ………........................................................................ 22



3.3.2 Repeated Stimulus Response .......................................................................... 22

3.4 Stimulus configurations.......................................................................................... 23

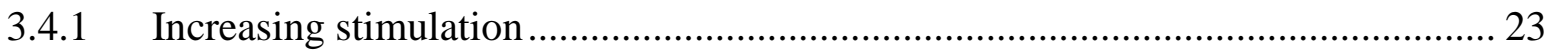

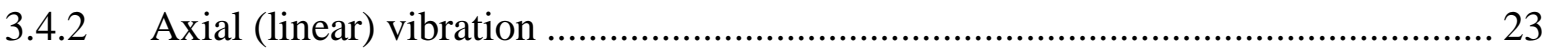

3.4.3 Radial (circular) vibration .............................................................................. 23

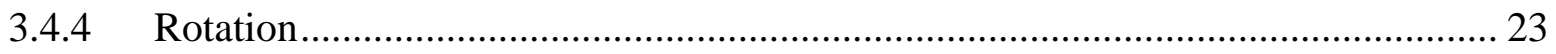

3.4.5 Repeated stimulation with and without rotation ............................................... 24

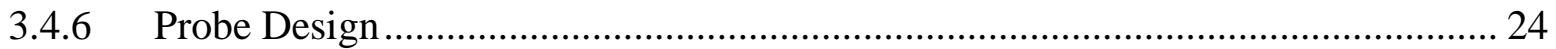

4 Pressure-pain using biaxial pressure algometry - single stimulus configuration ................. 26

4.1 Influence of linear vibration on pressure induced pain ................................................ 26

4.2 Influence of radial vibration on pressure elicited pain ................................................ 27

4.3 Influence of rotation on pressure produced pain ....................................................... 28 


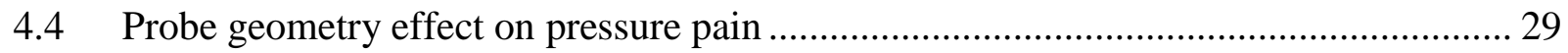

4.5 Biaxial stimulation effects on pain perception in NGF-induced muscle hyperalgesia .. 30

4.5.1 Pre-injection effects of biaxial stimulation on pressure pain.............................. 31

4.5.2 Post-injection effects of biaxial stimulation on pressure pain ............................ 31

5 Reliability and validity of pressure algometry ....................................................... 33

5.1 Variability of manual pressure algometry ......................................................... 34

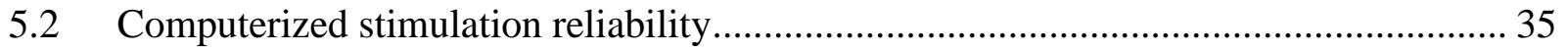

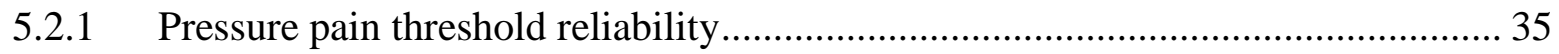

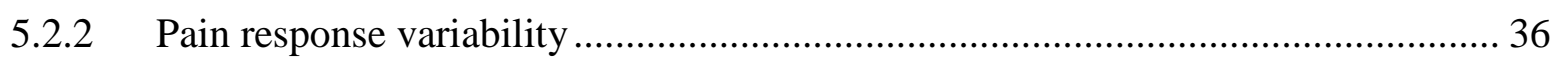

6 Influences of biaxial repeated stimulation on pressure evoked pain ................................ 38

6.1 Raw VAS scores - First pulse, Max VAS, and VAS-time area.................................. 38

6.2 Normalized VAS scores - Individual pulse effect and VAS Sum ............................ 39

6.3 Relation of frequency, stimulus duration, and rotation to pressure-pain ..................... 42

6.3.1 Painfulness of the first stimulus ..................................................................... 42

6.3.2 Frequency related temporal summation of pressure pain ................................ 42

6.3.3 Effects of stimulus duration on the temporal summation of pain ......................... 43

6.3.4 Effects of fanning probe rotation on the temporal summation of pain ................. 44

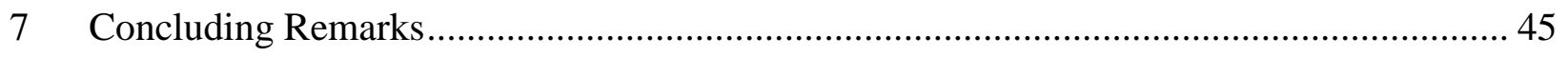

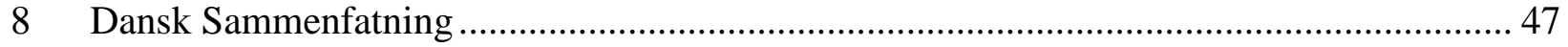

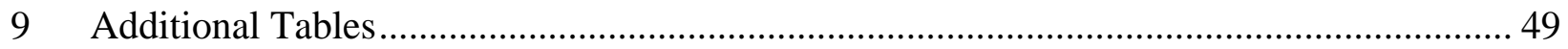

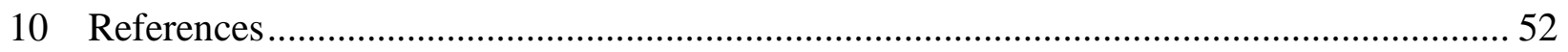




\section{Preface}

This $\mathrm{PhD}$ project is based on development and evaluation of the biaxial pressure algometer in studies conducted between January 2011 and December 2013 at the Center for Sensory-Motor Interaction (SMI), Aalborg University, Denmark.

\section{Technical Study}

Moving coil pressure algometer produces consistent force gradient and repeated stimulation;

Adnadjevic D, Graven-Nielsen T. Published in Conf Proc IEEE Eng Med Biol Soc.

\section{Study I}

Vibration and rotation during biaxial pressure algometry is related with decreased and increased pain sensation. Adnadjevic D., Graven-Nielsen T. Published in Pain Medicine.

\section{Study II}

Pressure algometry with a rotational fanning probe improves the detection of experimental muscle hyperalgesia. Adnadjevic D., Graven-Nielsen T. Accepted in Pain Medicine.

\section{Study III}

Temporal summation of pain evoked by very fast linear and rotational pressure sequences. Adnadjevic D., Graven-Nielsen T. Published in Somatosensory and Motor Research. 


\section{Acknowledgments}

I would like to thank my supervisor, Prof. Thomas Graven-Nielsen, for his insightful support and guidance. In addition, this thesis would not have been possible without the financial support of Obel Foundation, and assistance from the technical staff (Leif Jepsen, Søren Wøhlk Nielsen, Knud Larsen) as well as the secretariat (Lone Schødt Andersen, Debbie Pedersen, Susanne Nielsen Lundis) at the Center for Sensory-Motor Interaction. Finally, I would like to express my gratitude towards my colleagues, friends, and family for their unconditional support during my doctoral work in Denmark.

DJORDJE ADNADJEVIC

Aalborg University

June 2014 


\section{Introduction}

\subsection{Background}

Pain is a series of neuronal processes which involve the peripheral nerve network, spinal cord and brain. Perception of pain stimulus is due to spinal mechanisms and descending controls from the brain. This effectively means that bottom-up and top-down processes modulate transmission of stimuli and interactively generate the end stage pain perception (Graven-Nielsen et al., 2008). Assessment of pain sensitivity is crucial for a better understanding of the pain mechanisms such as peripheral (a reduction in threshold and an increase in responsiveness of the peripheral ends of nociceptors) and central (facilitated response to stimulation that is mediated by amplification of signaling in the central nervous system) sensitization. The pain sensitivity can be assessed by standardized painful stimulation and quantitative assessment of the outcome.

There exist different experimental musculoskeletal pain infliction methods, such as those pertaining to the exogenous group (electrical, thermal, chemical, mechanical) and others belonging to endogenous group (strenuous exercise, ischemia), to investigate mechanisms behind pain sensitivity, postural control, or muscle recruitment strategy during painful condition for instance (Graven-Nielsen et al., 2008). On a physiological level, painful stimuli are sensed by nociceptors located in the skin or musculoskeletal tissue. Physicians and scientists use various Quantitative Sensory Tests (QST) to assess the degree of pain and sensitization. Most notable ones include subjective user feedback scales such as visual analogue scales (VAS), verbal descriptor scales (e.g. Likert scale) and questionnaires (e.g. McGill Pain Questionnaire), and more objective sensitivity measures such as pressure-pain threshold (PPT) or heat pain threshold.

One type of mechanical exogenous assessment is called pressure algometry. It involves pressure stimulation of superficial and deep tissue with the help of the actuator driven probe (also called single point pressure algometry) or with the help of the tourniquet cuff that is pneumatically driven. These two techniques are considered more reliable in comparison to the handheld (manually driven) pressure algometer devices (Antonaci et al., 1998), since they are computer-controlled and therefore very precise in applying pressure stimulation. Additionally, they assure to the greater certainty that bias due to manual application is eliminated as in intraand inter-rater variability (user-independent). The disadvantage of the computer-controlled algometers is their size, restricted mobility and handful of custom-made associated accessories, such as supporting structures, driving mechanism, controlling computer etc. On the contrary, 
hand held algometers are highly portable, readily available on the market, and relatively inexpensive compared to the computer-controlled ones.

The refinement of the existing algometer stimulation setup includes the capacity of the new system to produce repeated, faster, stronger, and more accurate stimulation. This is highly interesting for assessment of some mechanisms in the central nervous system (e.g. temporal summation of pain) which might become sensitized in chronic pain patients due to constant nociceptive activity caused by neuropathy for instance (Graven-Nielsen and Arendt-Nielsen 2010). Today it is possible to stimulate musculoskeletal tissue at two second inter-stimulus intervals, but it would be of more interest to stimulate the tissue at higher rates with a reliable force-feedback control. Higher stimulation rate would provide further insights into effects of temporal summation on the pain perception for instance (Arendt-Nielsen et al., 1994; ArendtNielsen and Graven-Nielsen 2008), since qualitatively better (faster, stronger, more precise, multidirectional) pressure stimulation in humans could approximate better neuronal wind-up due to recurrent stimulation seen in animals (Mendell 1966).

Current point pressure algometry utilizes single spot stimulation of the somatic tissue, superficial and deep. One obvious issue with delivering only perpendicular stimuli is that this technique is not as sensitive as manual palpation to detect trigger points for instance (Reeves et al., 1986). One explanation might be that during manual palpation the deep tissue is stimulated both vertically and horizontally, and at various angles. However, manual palpation is inherently variable pressure application technique that is challenging to standardize even through consensus training (Degenhardt et al., 2005). Therefore, designing new stimulation technique that mimics the effect of manual palpation could potentially improve pain assessment methods via standardized electromechanical approach and facilitate awakening of deep tissue neurons.

In order to achieve better understanding of pain physiology and pain assessment techniques, this PhD study focuses on single point pressure algometry. More particularly, the project investigated possible improvement paths of the entire stimulation system (pulse delivery mechanism, stimulation paradigms, timing effects, probe design) in attempt to standardize its usage and deliver improved single and repeated stimulation such that new insights into pressurepain are gained. 


\subsection{Aims of the PhD Project}

The flowchart of the $\mathrm{PhD}$ project is shown in Fig. 1, with the following aims:

1) Understanding and exploring biomechanical mechanisms essential to deep tissue stimulation in normal and hyperalgesic tissue. Such objective can be attained by designing a reliable stimulation system mimicking the pressure stimulation done during manual palpation (Technical Study and Study I). The perception is that deep tissue stimulation during manual palpation is performed multi-directionally with varying intensity (Ahn et al., 2012). It is hypothesized that rotational force, vibration, probe geometry and its qualitative properties will induce such a distinct peripheral neuronal response in normal and hyperalgesic deep tissue muscles (Study I and II, respectively).

2) Enhancing repeated stimulation timing, accuracy, and strength to better understand underlying mechanisms of pain responsible for inducing central response. This could be achieved by improving the existing computer-controlled stimulation methods, such that the somatic tissue is stimulated accurately at higher rates and forces (Technical Study) as well as in multiple directions. It is hypothesized that repeated, multidirectional, and accurate stimulation will contribute to facilitated central response manifested in temporal summation of pain due to recurring stimulation pulses (Study III). 




Fig. 1. Schematic representation of the $\mathrm{PhD}$ project investigating pain mechanisms behind pressure evoked pain applied via biaxial algometer is shown, where the colored lines link aspects examined in each study. Biaxial algometer was developed and its consistency to produce repeated and increasing stimulation as well as technology behind it was described in TS. It was subsequently used in three studies to assess pain thresholds (PPT) and pain perception (VAS) during application of novel stimulation methods (rotation, radial and axial vibration) as well as their reliability in normal (Study I) and hyperalgesic (Study II) muscle and to investigate most optimal bidirectional repeated stimulation parameters to induce temporal summation of pain (Study III). 


\section{Mechanisms of pressure-pain and principles of pain measurement}

\subsection{Basic traits of muscle mechano-nociception}

Somatic pain occurs in skin, muscles, tendons, and joints and is mediated through the afferent nerve fibers caudally towards the spinal cord and the brain. Pain is additionally affected by the descending controls from the brain (Gebhart 2004), where peripheral and central pathway convergence results in the final pain perception. Painful stimuli is sensed by nociceptors whose existence was first suggested in 1906 (Burke 2007). Musculoskeletal pain is sensed in response to stimulation of deep-tissue pain receptors pertinent to group III and group IV (A $\delta$ and C) afferent fibers (Mense 1993). These polymodal fibers responding to chemical, thermal, mechanical stimulation (Kumazawa and Mizumura 1977) can secrete sensitizing neuropeptides that trigger nociceptor sensitization and even hyperalgesia.

$\mathrm{A} \delta$ - and C-fibre mechanically sensitive afferents (MSAs) react to punctate mechanical stimuli. When a predetermined force stimulus is applied to the receptive field, the response is largest at the beginning of the stimulus and then decreases until it adapts. Repeated presentations of a mechanical stimulus lead to pronounced fatigue. The A-fibre nociceptors (thinly myelinated A $\delta$ fibers, with a conduction velocity of 6-30 m/s) recover faster from fatigue than the C-fibre (unmyelinated, with a conduction velocity of less than $2 \mathrm{~m} / \mathrm{s}$ ) nociceptors, which on the hand signal pain from tonic pressure. If prolonged mechanical stimuli are applied to human subjects, the pain intensifies during the stimulus (Adriaensen et al., 1984). Nonetheless, the response of MSAs to long-duration suprathreshold stimuli attenuates with time. Although C-fibre are, per se, normally insensitive to mechanical stimuli, they develop a response to prolonged mechanical stimulation (Schmidt et al., 2000). Additionally, the pain associated with a tonic stimulus persists through a selective A-fibre block (Andrew and Greenspan 1999), suggesting that C-fibre signal the pain related with constant pressure input.

Should there be a prolonged noxious input via recurrent stimulation paradigm of the unchanged stimulus intensity, a progressive build-up of dorsal horn neuron (DHN) activity will lead to a phenomenon of a neuronal wind-up (Mendell 1966), which is a correlate of the temporal summation of pain in humans (Arendt-Nielsen et al., 1994; Arendt-Nielsen and Graven-Nielsen 2008). This maintenance of nociceptive input leads to sensitization of DHN instigating receptive field expansion of the neuronal fibers and a facilitated response to painful as well as and non-painful stimulations (Mense et al., 2001). The most pertinent knowledge about 
the characteristics of deep-tissue nociceptors is based on recordings in rats and cats (Mense 1981), and a human study that used microneurography (Marchettini et al., 1996).

Musculoskeletal pain is manifested as localized, regional or widespread pain and can be rationalized by increased pain sensitivity of nociceptors located in deep tissue (peripheral sensitization) or by increased responses from DHN (central sensitization). The spreading of pain and increased neuronal excitability (sensitization) is related to amplified synaptic activity in central neurons and to modulations in descending control from higher centers (Graven-Nielsen and Arendt-Nielsen 2010). Further knowledge with regards to particular mechanisms in musculoskeletal pain could be attained via quantitative sensory testing and quantitative assessment of pain, described in the following subsection.

\subsection{Quantitative sensory testing}

Quantitative Sensory Testing is an important method for diagnosing peripheral and central nervous system disorders, ranging from small changes in sensibility (Greenspan et al., 2004) to chronic pain (van Wilgen et al., 2013). QST fundamentally determines the sensation and pain thresholds for e.g. cold and warm temperatures, vibration sensation and pin-prick threshold by stimulating the skin (Boivie et al., 1989; Boivie et al., 1994), and especially pressure-pain thresholds which are more relevant for quantifying deep tissue sensitivity (Kosek et al., 1993). When the stimulus activates stimuli-specific receptors then the nerve fibers innervating the receptors transmit the stimuli's message to the central nervous system where the perception occurs. The subject subsequently evaluates the amount of perceived pain on an electronic VAS or verbal scale, through a pain questioner or by ceasing the stimulation thus indicating what the thermal, electrical, or mechanical pain threshold was. Quantitative Sensory Testing is a noninvasive, exogenous technique that can assist in early detection, therapy selection and monitoring the progression and recovery of patients with peripheral and central sensory disorders such as fibromyalgia (Hurtig et al., 2001) and whiplash pain (Chien et al., 2008), for instance.

QST can be used to induce temporal (response obtained from successive stimuli) and spatial summation (addition of simultaneous stimuli on increased stimulation area) of pain, to detect hyperalgesia (characterized by increased responsiveness, where noxious stimuli produce an exaggerated and prolonged pain) and allodynia (characterized by the lowering of thresholds, where stimuli that would normally not produce pain now begin to hurt), in order to assess sensitivity to pressure pain (Zaslansky and Yarnitsky 1998). Standardized stimulation parameters 
could be crucial in diagnosing pain disorders such as systemic hypersensitivity to stimulations that are not usually painful in healthy population. By measuring amount of temporal summation of pain in the form of a rate of pain change versus time, it is possible to determine whether the subject suffers from central nervous pain sensitization, which is important for paving the proper path of analgesic treatment in the chronic pain patients (Hurtig et al., 2001; Boivie 2003). Further, standardized stimulation techniques could be useful in detecting tender spots in muscular tissue as well as trigger points (taut bands in the muscle) in a more robust manner, which is important for quantifying the level of pain chronicity (Amris et al., 2010).

\subsection{Pressure algometry}

This subsection will introduce the chronological development and up-to-date situation on single point pressure algometers, although tourniquet cuff algometers will be briefly mentioned as well. Such apparatus can be used to detect hyperalgesia, induce temporal and induce spatial summation in order to quantify pressure-pain sensitivity.

\subsubsection{Single point pressure algometry - unidirectional stimulation}

Hand-held single point pressure algometers are not computer-controlled, neither are they automated. However, they have a long history of development, contrary to computer-controlled ones. In addition, they are most used commercially and clinically. These devices have been used since Victorian times (Keele 1954), and their operating mechanism ranged from purely mechanical principles (for instance adding weights to asses pain thresholds (Rainwater and Mcneil 1991), having springs of different compressibility levels (Buchanan and Midgley 1987), having calibrated syringe with a plunger (Johnson and Watson 1997)), to the modern ones that provide examiners with force feedback depending on the force application rate (Tenbokum and Lavigne 1997). Commercially available ones are for example Somedic Algometer (Somedic AB, Sweden), Force One FDIX 50 (Wagner Instruments, Greenwich, Connecticut, USA), and Commander Algometer (JTECH Medical, Salt Lake City, Utah, USA). Quality of pain assessment with these hand-held algometers often depends on the amount of practice that physician has had with a particular device. This potentially means that pain assessment with hand held single point pressure algometers is difficult to standardize even after hours of practice, as alertness, consciousness, and affection of the observer could be pivotal in determining the pressure pain threshold (Hogeweg et al., 1992). 
Single point computer-controlled pressure algometers are custom-built and available usually in a laboratory setting (Graven-Nielsen et al., 2004; Xiong et al., 2010; Zimkowski et al., 2011; Koo et al., 2013), although some devices are gaining market momentum as well (Kruger et al., 2011; Harte et al., 2013). Therefore, they are rare and often cumbersome to transport from the laboratory setting to the on-site usage at the clinic for instance. An overview of the computerized devices is presented in Additional Tables section, Table A. One of these custommade devices is located at the Center for Sensory-Motor Interaction (SMI) at Aalborg University, Denmark (Graven-Nielsen et al., 2004). The experimental setup includes i) actuatordriven single point pressure algometer with changeable stimulation probes, ii) computer control unit and, iii) electronic visual analogue scale for immediate pain quantification. The current setup is able to effectively stimulate the somatic tissue at the $0.5 \mathrm{~Hz}$ frequency. Although higher rates are also possible $(1,2,4$, and $5 \mathrm{~Hz})$ their force impact has limited effectiveness due to the internal gear mechanism. In addition, the computer control of the setup allows for constant force stimulation, as well as for the force gradient (typically used when assessing pressure pain thresholds and pain tolerance limits). Finally, the current experimental setup at the Laboratory for Experimental Pain Research has three degrees of freedom, which permits application of force along a programmable path, defined by a set of points.

\subsubsection{Cuff algometry}

Contrary to single point pressure application devices, there exist algometers that stimulate larger body areas, also known as tourniquet cuff pressure algometers. The cuff algometer activates a larger volume of the deep somatic tissue than the pressure algometry. The experimental setup consists of a pneumatic tourniquet cuff, a computer-controlled air compressor and an electronic VAS scale for constant pain induction and pressure-pain threshold quantification (Polianskis et al., 2001; 2002b; a). Cuff pressure algometers induce spatial summation of pain - addition of simultaneous stimuli from several conducting nerve fibers - due to the larger area of somatic tissue that is stimulated. For instance, Jespersen et al. used cuff pressure algometry to evaluate its performance in patients with fibromyalgia (Jespersen et al., 2007).

\subsubsection{Pressure algometry - pros and cons}

Positive features for manual pressure algometry relative to the computerized algometry and vice versa are shown in the lists below, where the last point in each list addresses the validity and 
variability aspects of the algometry. Although not guaranteed, experience obtained through repetitive training procedures could improve the reliability aspect of handheld algometry. On the other hand, computerized algometry ought to be validated in the technical and experimental trials as these devices are often one-of-a-kind prototypes. Reliability aspects are further discussed in Chapter 5 and the validity overview of the recent computerized algometers is shown in Additional Tables section, Table A.

\section{Handheld algometry}

- Portable, readily available, simple to use, and relatively inexpensive

- Measurements are not restricted to limbs

- Assessment angle can be adjusted leading to perpendicular pressure application

\section{Computerized single point algometry}

- Custom design allows for electronic sampling of pain, force, blood pressure profiles etc.

- Offers wider range of pressure application paradigms

- Compression rate is controlled via automatized pressure feedback

- Larger body parts can be assessed with the customization of the setup

- Reduced training time and variability

\section{Computerized cuff algometry}

- Portable, not readily available

- Custom design allows for electronic sampling of pain and force

- Offers wider range of pressure application paradigms

- Compression rate is controlled via automatized pressure feedback

- Larger body parts can be assessed with the customization of the setup

- Skin pain perception is surpassed due to deep tissue stimulation (Polianskis et al., 2002a)

- Spatial summation of pain aspect can be assessed most effectively via cuff algometry

- Reduced training time and variability 


\section{Biaxial pressure algometry - bidirectional stimulation}

\subsection{Rationale}

Recent advancements in the field of the computer-controlled algometry include biaxial algometers that operate with higher accuracy, speed, and force owing to more advanced drive mechanisms of the setup (Adnadjevic and Graven-Nielsen 2012). These advancements effectively mean that researchers as well as clinicians can more confidently rely on the measured outcomes, e.g. sensitivity to pressure induced pain.

Efforts during basic research studies have been made to reproduce parts of the manual palpation performed by clinicians while detecting taut bands of muscular tissue with the unidirectional pressure algometer, resulting in an improved understanding of the motion/force profiles underlying palpation. However, palpatory motion involves more than one degree-offreedom as shown in Fig. 2: clinicians are not only adjusting the down force, but are also performing the rolling of the thumb against the stimulated muscle (Adnadjevic et al., 2013a) - a factor that is missing in today's pressure algometry. 

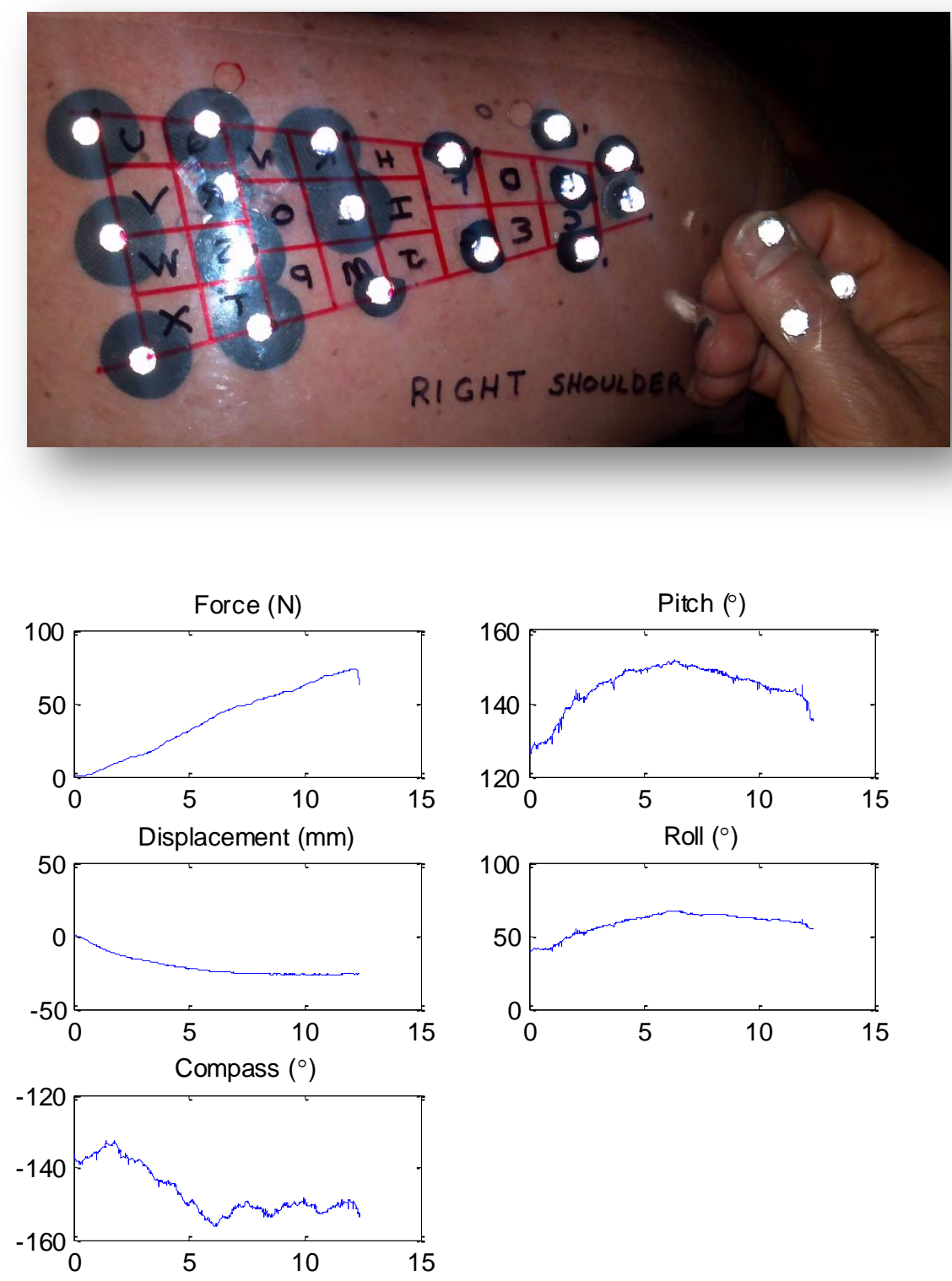

Fig. 2. Top: Typical manual palpation recordings via 3D camera system and force recording foils placed on top of the trapezius muscle (Adnadjevic et al., 2013a). Bottom: Constant force is applied via thumb displacing the tissue in several directions. Thumb motion shows minimal change in the roll angle, while the angle of attack (pitch) is changing over time by 20 degrees. Compass angle is simultaneously oscillating approximately 15 degrees as the examiner is trying to locate the tender spot. Note that the angle values are presented in relation to the position of the markers placed on the examiners thumb (pitch and roll) as well as to those on the back of the subject (compass). 


\subsection{Stimulation setup}

Two-axis stimulation of the musculoskeletal tissue has shown that the inclusion of the second axis (rotation) adds distinctive pain perception quality compared to a single (linear) axis, consequently contributing to more effective methods of pressure stimulation (see section 3.1). The device consists of a pointy end (stimulation element, probe) which is operated through a set of electromechanical drivers and controlled via computer where linear and rotational axes can be controlled independently and synchronously. The stimulator can apply pressure in the linear (axial, $\mathrm{F}_{\mathrm{z}}$ ) and circumferential (radial, $\mathrm{M}_{\mathrm{z}}$ ) directions where stimulation element leaves the housing and makes the contact with the skin-muscle surface as it rotates around the linear axis or vibrates any of the axes (Fig. 3). Stimulation element applies mechanical pressure in various directions for a certain time and at a precisely defined intensity, and is capable of repeating this process "indefinitely" (hours) while the person who receives stimulations rates pain perception via an electronic scale. This device gives to the test subject an option to act on the button which prevents the actuator from exerting the force, thus marking the pressure-pain threshold (PPT) or the pressure pain tolerance limit (PPTo). 

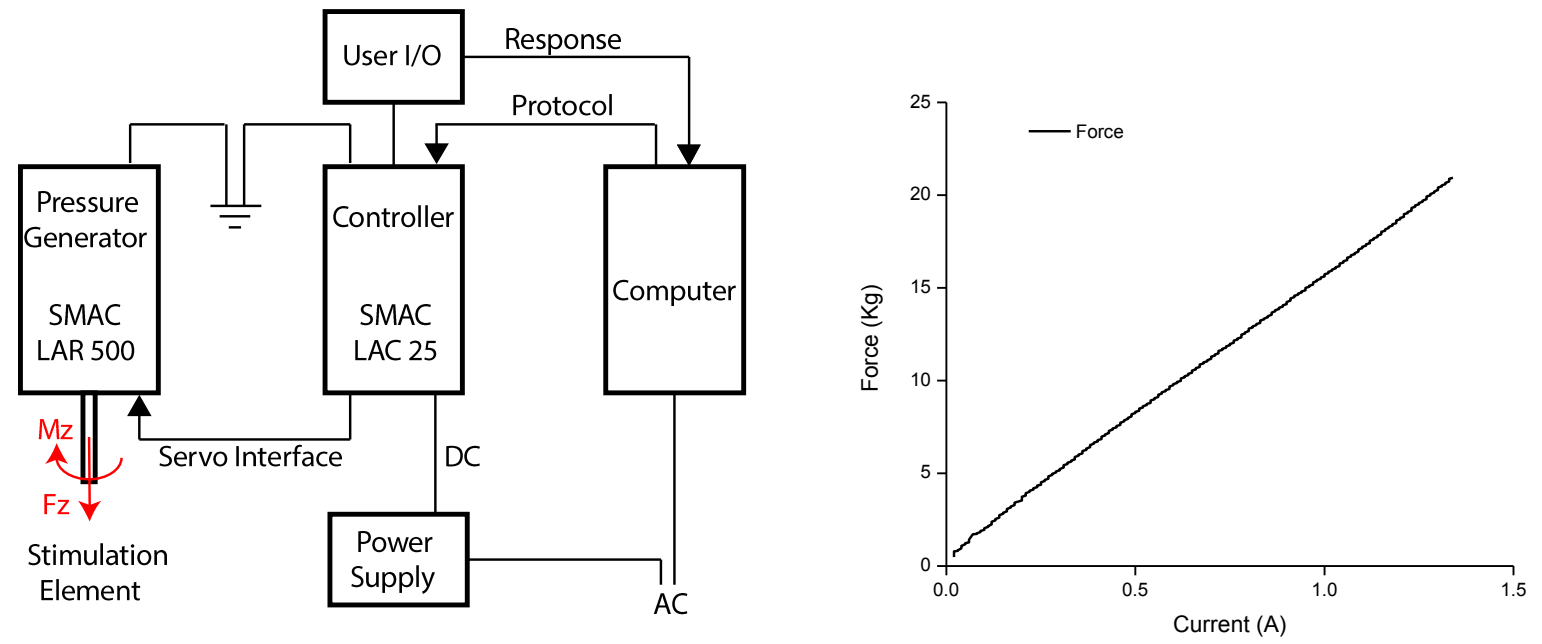

Fig. 3. TS - Biaxial Algometer Schematic (modified from (Adnadjevic and Graven-Nielsen 2012)). Left: Electromechanical multiple degree-of-freedom stimulator comprises of an actuating piston (stimulation element (SE)) which leaves pressure generator housing and retracts into it depending on the desired motion/force profile. Controller mediates the RS232 communication protocol through the servo interface to the pressure generator. User I/O includes a pain response interface (VAS scale), subject operated stimulation STOP button, and calculating means arranged to output a measure of perceived pain of a subject as well as the force profile at the contact site. Right: The force constant of $15.1 \mathrm{~kg} / \mathrm{A}$ and a 10 bit $\mathrm{A} / \mathrm{D}$ converter result in $55 \mathrm{~g}$ of force resolution.

Fast switching between three programmable modes of operation (position, velocity, and force) enables the algometer to perform at speeds faster than $1 \mathrm{~m} / \mathrm{s}$ or low speeds within five micron accuracy and repeatability. Such performance characteristics are of pivotal importance for reliable data collection during pressure-pain sensitization studies. Repeated stimulations with consistent force profile of different strength are presented in Fig. 4; however, integration of all three modes of operation is needed to reduce the overshoot of the impact during repeated stimulation process by applying the soft land routine. 



Fig. 4. Repeated stimulation paradigm. Left: Consistent 10-pulse train is executed in the force mode with each pulse lasting $500 \mathrm{~ms}$ and inter-pulse time of $100 \mathrm{~ms}$. Right: Optimized soft land parameters reduce overshoot as the routine integrates fast switching among position, velocity, and force modes of operation during delivery of each pulse.

The biaxial algometer safety system includes an emergency red mushroom button that controls supply current powering the electromechanical system and the load-cell triggered power-off relay which can either cut the power to the system or instruct retract command once undesired force is reached (overload protection). Pressure levels are feedback controlled by a load cell (8435-5500 Burster, Germany), which is attached above the stimulation element on the biaxial algometer, and recorded at $1000 \mathrm{~Hz}$ (NI PCI-6221, National Instruments, Austin, Texas, USA). Finally, due to strong stimulation capabilities $(50 \mathrm{~kg})$, the custom designed and specifically gauged mechanical fuse mounted between the algometer and the stimulation element acts as an impact buffer for forces larger than $25 \mathrm{~kg}$, shown in Fig. 5 (Adnadjevic et al., 2013b). 


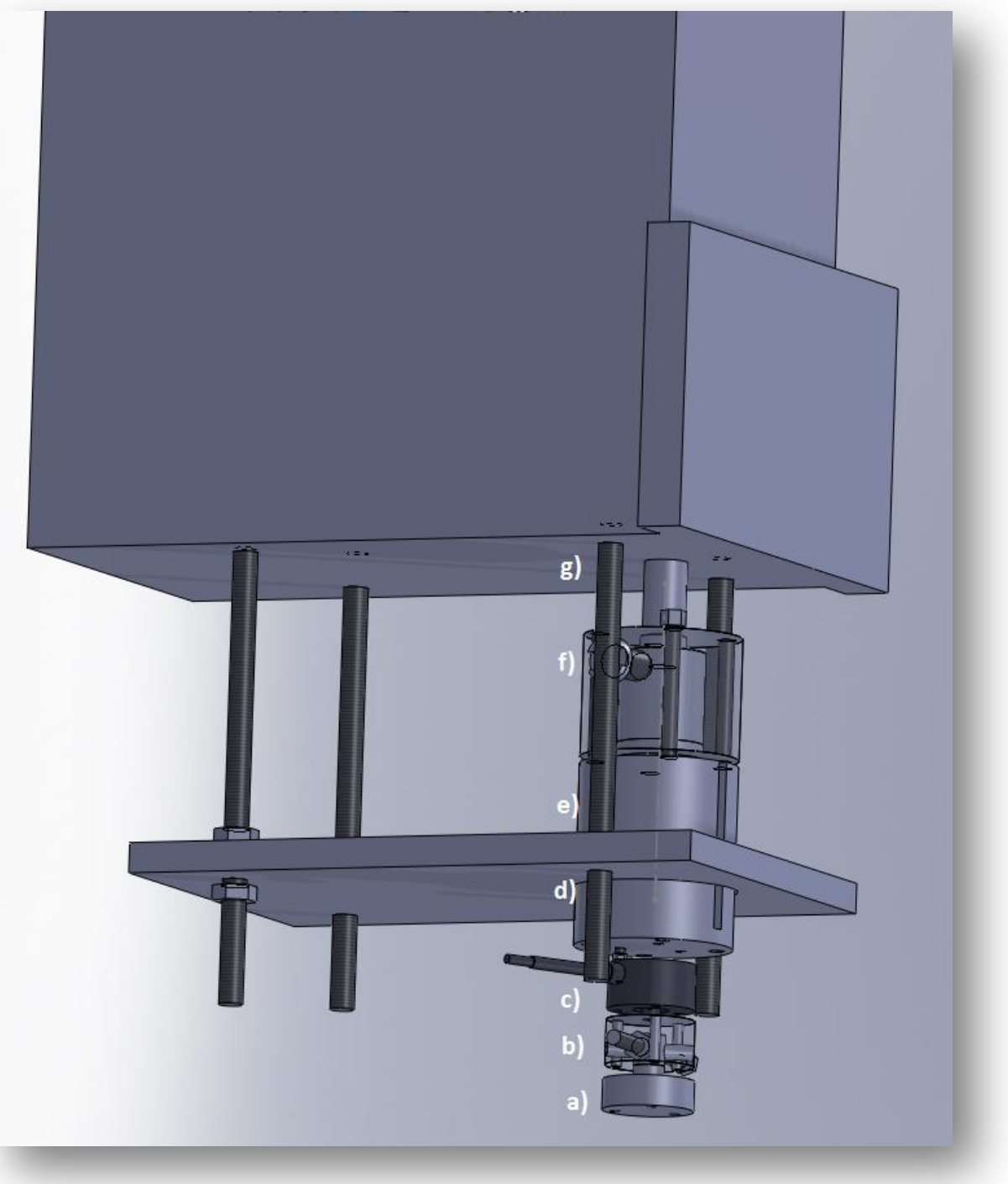

Fig. 5. New biaxial algometer and mechanical safety fuse: a) stimulation probe; b) probe adapter/stabilizer; c) Burster load cell; d) anti-moment plate; e) safety buffer; f) load gauge screw; g) actuator. 


\subsection{Pain response measurement}

Electronic visual analogue scale (VAS) is nominally used in the experimental setting due to its ease-of-use and convenient method of recording. The ease-of-use rests in the fact that the pain definition points are arbitrary and can be tailored to the needs of the experiment. For instance, Nie et al. anchored the "no pain" score at VAS $=0$, whereas "worst imaginable pain" rested at VAS $=10$ (Nie et al., 2005). In other cases, resolution of the scale for the pain assessment may be reduced if pain threshold is defined at $\mathrm{VAS}=5$; consequently, the pressure-only response i.e. no-pain sensation, can be assessed in the range VAS $<5$. In studies pertinent to this thesis, the VAS signal was sampled at $1000 \mathrm{~Hz}$ rate via data acquisition board (NI PCI-6221, National Instruments, Austin, TX, USA) and its usage is described below.

\subsubsection{Single stimulus response}

The ten centimeter long electronic VAS was anchored with 0 representing 'no pain' and $10 \mathrm{~cm}$ defining 'the first instance of pain strong enough to make one feel like stopping the stimulation'. Subjects were instructed that their pressure pain threshold rests at $5 \mathrm{~cm}$ on the VAS, whereas stimulations perceived as more painful should be rated above this value, and those that are not painful but nonetheless give certain pressure sensation should reside in the bottom half of the scale. The maximum VAS scores were extracted and analyzed in Study I and II.

\subsubsection{Repeated Stimulus Response}

Similarly, the ten centimeter long electronic VAS was used by the subjects to assess the perception of the pressure stimulation $(0 \mathrm{~cm}$ representing 'no pain' and $10 \mathrm{~cm}$ representing 'maximum pain'). Subjects were instructed that their PPT rests at VAS $=5 \mathrm{~cm}$, whereas stimulations perceived as more painful should be rated above this value, and those that are not painful but nonetheless give certain pressure sensation should rest in the bottom half of the scale. The subjects continuously scored the perceived sensation on the VAS scale and were instructed not to return it back to zero in-between repeated stimuli. Maximum VAS score, area under the VAS-time curve, VAS value at each pulse in the train and sum of these individual values normalized by subtraction to the first pulse, were extracted and analyzed in Study III. 


\subsection{Stimulus configurations}

\subsubsection{Increasing stimulation}

Continuous increasing pressure stimulation of $0.30 \mathrm{~kg} / \mathrm{s}$ was used to assess pressure pain thresholds on several points along the tibialis anterior muscle (Study I) and on the belly of the brachioradialis muscle (Study II). The PPTs were measured at least three times at every stimulation site and then averaged for each site. Subsequently, the rate of $1 \mathrm{~kg} / \mathrm{s}$ (Study I and II) was used to reach 75,100 , or $125 \%$ PPT stimulation intensity levels, after which axial vibration, radial vibration, or rotation were applied for 5 seconds.

\subsubsection{Axial (linear) vibration}

After reaching the 100 or $125 \%$ PPT individual stimulation intensity level (Study II and I, respectively), axial vibration of 15,25 , or $50 \mathrm{~Hz}$ was applied on top of the basic pressure. The peak to peak amplitude varied in the $10-20 \%$ range of the respective PPT, and the stimulation lasted for 5 seconds during which subjects rated their pain perception on the VAS scale.

\subsubsection{Radial (circular) vibration}

Once the 75,100 , or $125 \%$ PPT stimulation intensity levels were attained, vibrational stimulation in the circumferential direction was added on top of the fundamental (basic) pressure. The vibration motion was first executed in the anticlockwise and then the clockwise direction where the stimulation element moved 5 degrees back and forth at 5,15 or $25 \mathrm{~Hz}$ for 5 seconds (Study I and II). Subjects were to opine their pain perception on the VAS scale.

\subsubsection{Rotation}

Rotation paradigm used in Study I and II consisted of the fundamental (basic) pressure combined with rotational movements of 45, 90, or 180 degrees applied at all three PPT intensity levels (75, 100, or $125 \%$ PPT). Each stimulus lasted for five seconds and due to this time constraint, $45^{\circ}$ and $90^{\circ}$ stimulations traveled back and forth twice and once respectively at the same speed (6 revolutions/ min), whereas $180^{\circ}$ stimulus traveled there and back once at an elevated speed (12 revolutions/ min). Similarly, for this modality subjects also had to rate their pain perception on the VAS scale. 


\subsubsection{Repeated stimulation with and without rotation}

For the repeated stimulation paradigm (Study III), phasic PPT was determined at the tibialis anterior muscle by computer-controlled stimulation of three consecutive square stimuli without rotation, each of $500 \mathrm{~ms}$ duration separated by five seconds breaks, where the skin contact was maintained at $0.5 \mathrm{~kg}$. The subjects were to opine the perceived pressure-induced sensation of the three stimuli on the VAS. The stimulation intensity was initially $0.5 \mathrm{~kg}$ and then increased in steps of $0.5 \mathrm{~kg}$ until the VAS $=5 \mathrm{~cm}$ was reached.

Recurrent stimulation train consisted of 15 pulses applied at the $100 \%$ PPT intensity level (Study III). Stimuli were delivered at $0.5,1$, or $1.5 \mathrm{~Hz}$ frequency, where the maximal pressure contact time was varied (500 vs. $300 \mathrm{~ms}$ ). Fast ramp of $20 \mathrm{~kg} / \mathrm{sec}$ reached $100 \%$ PPT intensity during the application of the pulses while probe-to-skin contact was maintained between the 15 stimuli at the $20 \%$ PPT intensity during the refractory period. In some conditions, the stimulations had additional rotational movement in the clockwise direction at the speed of 0.05 revolutions/ sec (3 revolutions/ $\mathrm{min}$ ).

\subsubsection{Probe Design}

Probes geometries presented in Fig. 6. were designed to mimic shape of the thumb which is used to palpate tissue during physical examination. When thumb is applied perpendicularly to the stimulation site such as musculoskeletal tissue, it allows for a redistributed force application due to its rounded shape and circumferential movements often associated with manual palpation. As a consequence, more tissue is displaced during rotational movements and implications of such probe geometry were examined in Study I and II, wherefrom the learned efficacy of each probe was tailored to the protocol of Study III. 


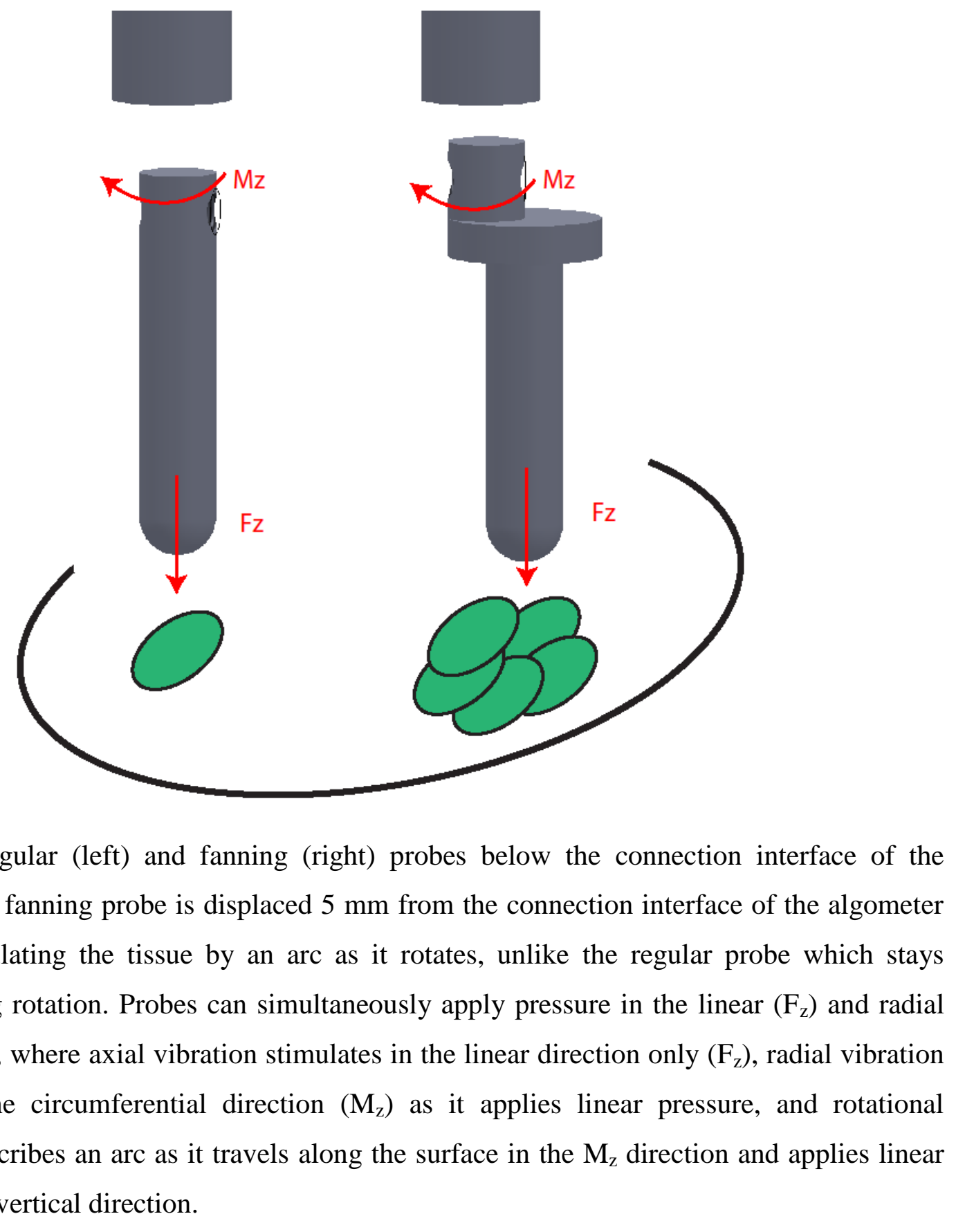

Fig. 6. The regular (left) and fanning (right) probes below the connection interface of the algometer. The fanning probe is displaced $5 \mathrm{~mm}$ from the connection interface of the algometer therefore stimulating the tissue by an arc as it rotates, unlike the regular probe which stays centered during rotation. Probes can simultaneously apply pressure in the linear $\left(\mathrm{F}_{\mathrm{z}}\right)$ and radial $\left(\mathrm{M}_{\mathrm{z}}\right)$ directions, where axial vibration stimulates in the linear direction only $\left(\mathrm{F}_{\mathrm{z}}\right)$, radial vibration oscillates in the circumferential direction $\left(\mathrm{M}_{\mathrm{z}}\right)$ as it applies linear pressure, and rotational stimulation describes an arc as it travels along the surface in the $\mathrm{M}_{\mathrm{z}}$ direction and applies linear pressure in the vertical direction. 


\section{Pressure-pain using biaxial pressure algometry - single stimulus configuration}

\subsection{Influence of linear vibration on pressure induced pain}

Effects of axial vibration on pressure pain were explored in Study I, where axial vibration on top of the basic suprathreshold stimulation reduced VAS scores (diminished painful sensation) compared to the basic stimulation alone, regardless of the frequency used (Fig. 7). This is concordance with previous studies (Kakigi and Shibasaki 1992) where it was shown that vibration modulates nociceptive afferent input from the laser stimulation or that it somewhat alleviates orofacial pain (Hansson and Ekblom 1986). A more recent study showed among other findings that $80 \mathrm{~Hz}$ vibration together with pressure compared to standalone pressure reduces soreness (increases pain thresholds) in the gastrocnemius soleus muscle complex (Weerakkody et al., 2003). The presence of pain relief by vibration is confirmed in the current data, which is consistent with the gate control theory (Melzack and Wall 1996). Finally, the whole body vibration was shown to reduce and even prevent delayed onset muscle soreness in athletes when exposed to it before eccentric exercise (Bakhtiary et al., 2007; Aminian-Far et al., 2011; Wheeler and Jacobson 2013), showcasing the therapeutic effect it may have on the overall pain perception.

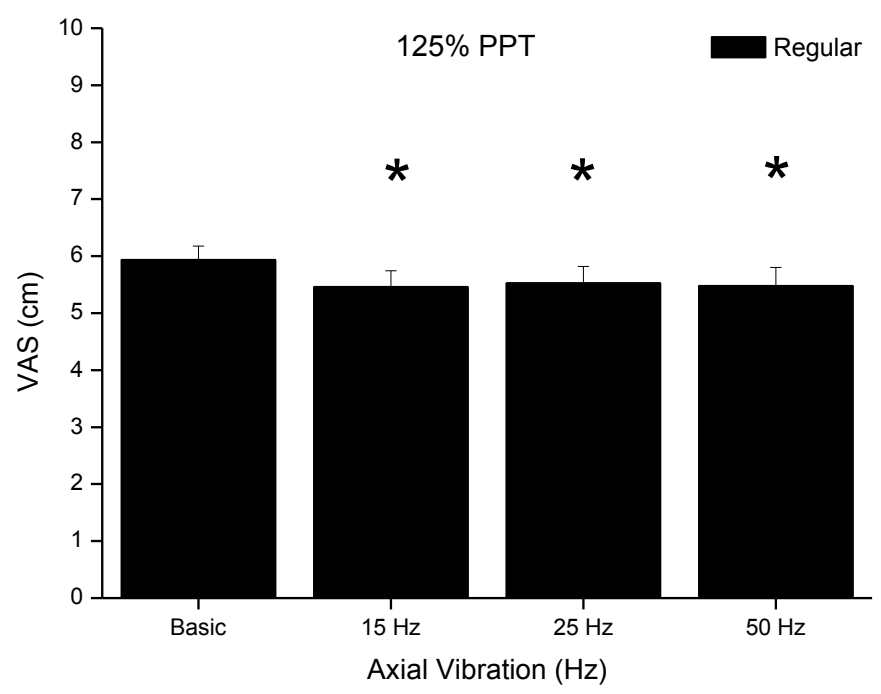

Fig. 7. Vibration on top of the basic pressure yielded reduced VAS scores relative to the basic pressure alone (125\% PPT), Mean (+ SEM, N = 24). Stimulations were applied via regular probe and asterisk (*) denotes significantly lower VAS scores (BON: P < 0.05) compared with basic. 


\subsection{Influence of radial vibration on pressure elicited pain}

Study I additionally examined effects of radial vibration on VAS scores. For all the stimulation intensities, basic stimulation is perceived as less painful than the 5 and $15 \mathrm{~Hz}$, and as painful as $25 \mathrm{~Hz}$ stimulation. Interestingly, relative to suprathreshold (125\% PPT) $25 \mathrm{~Hz}$ axial vibration stimulation (Fig. 7), $15 \mathrm{~Hz}$ radial vibration at the same intensity and with the regular probe is perceived as more painful in relation to its respective fundamental pressure (Fig. 8c). This may be due to the mixed nature of radial vibration (rotation describing a small travel angle combined with vibrating frequency). Thus, it could be that phenomenon of spatial summation reflected in rotation competes with the effect of an inhibitory mechanism due to vibration (linear pressure).
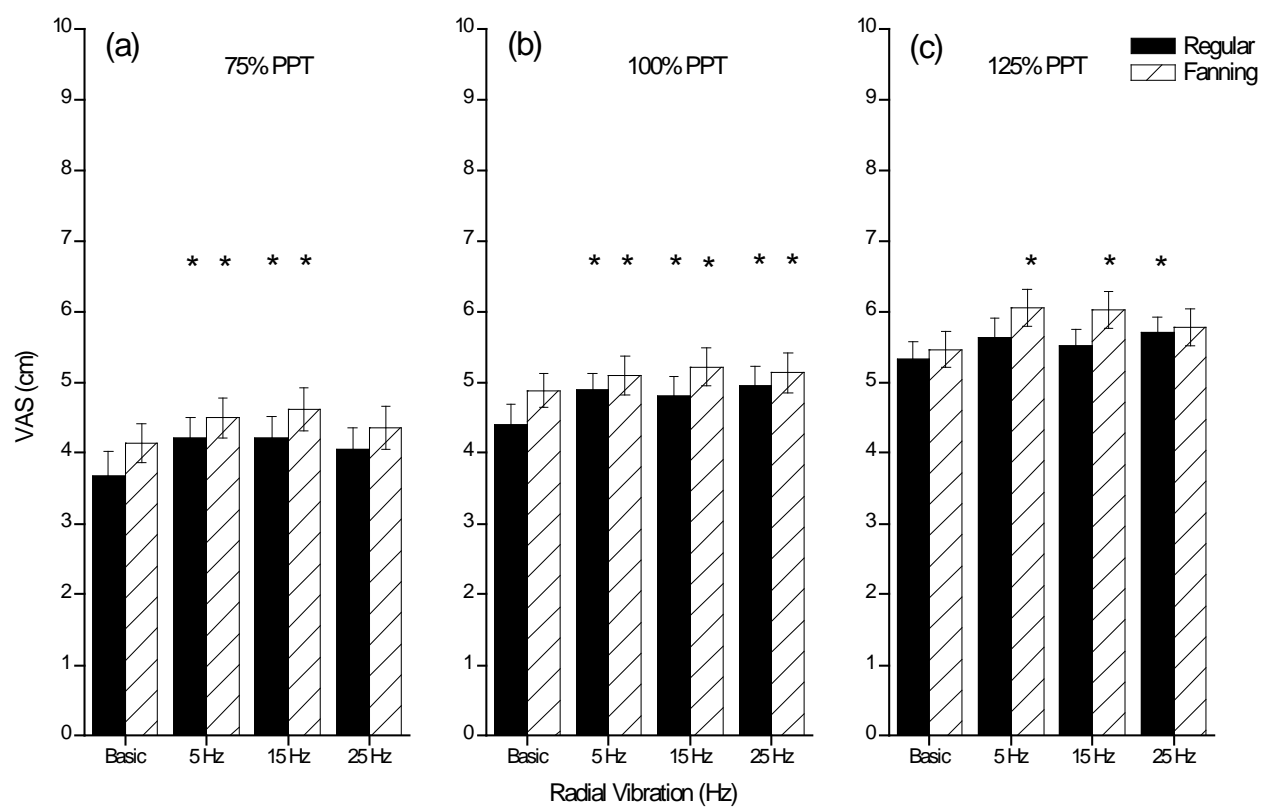

Fig. 8. Mean (+ SEM, $N=24)$ VAS scores after pressure stimulation with radial vibration (a-c) paradigm at 75, 100, and 125\% PPT intensities for the regular and fanning probes (Study I). Significantly different VAS scores (BON: P < 0.05) compared with basic $(*)$.

Noteworthily, radial vibration exhibited lesser VAS scores compared to the rotational stimulation at each respective intensity (Fig. 8 vs. Fig. 9). It is speculated that due to the limited angle of vibration, spatial summation is probably less pronounced compared with the larger angle rotations associated with rotational stimulation. 


\subsection{Influence of rotation on pressure produced pain}

Study I showed that the larger tissue displacements by rotation corresponded to a higher pain perception (Fig. 9). The increase in pain ratings with the increase in rotational stimulation angle could be attributed to spatial summation phenomenon. It is possible that the increase in rotational travel angle is more effectively increasing strain on the deep structures having an effect of increasing the nociceptive afferent impulses to the central nervous system (CNS). Even though conventional spatial summation (Nie et al., 2009) is not admittedly happening here, it may be a comparable paradigm since a larger area of tissue is stimulated over a short time period contributing to better recruitment of nociceptors of the deep tissue especially with the fanning probe.

It could be challenging to separate the skin and deep tissue nociceptive input and clearly state which of the two makes rotational stimulation more painful due to probable meeting point of somatic and cutaneous nociceptive neurons at the same dorsal horn (Mense 1981). Jensen et al showed that skin sensitivity could influence pain perception elicited by pressure stimulation (Jensen et al., 1986), but a more recent study showed that mechanical pain sensations can be felt even with complete skin anaesthesia, reckoning that the pain most likely came from the deep musculoskeletal tissue (Graven-Nielsen et al., 2004). 

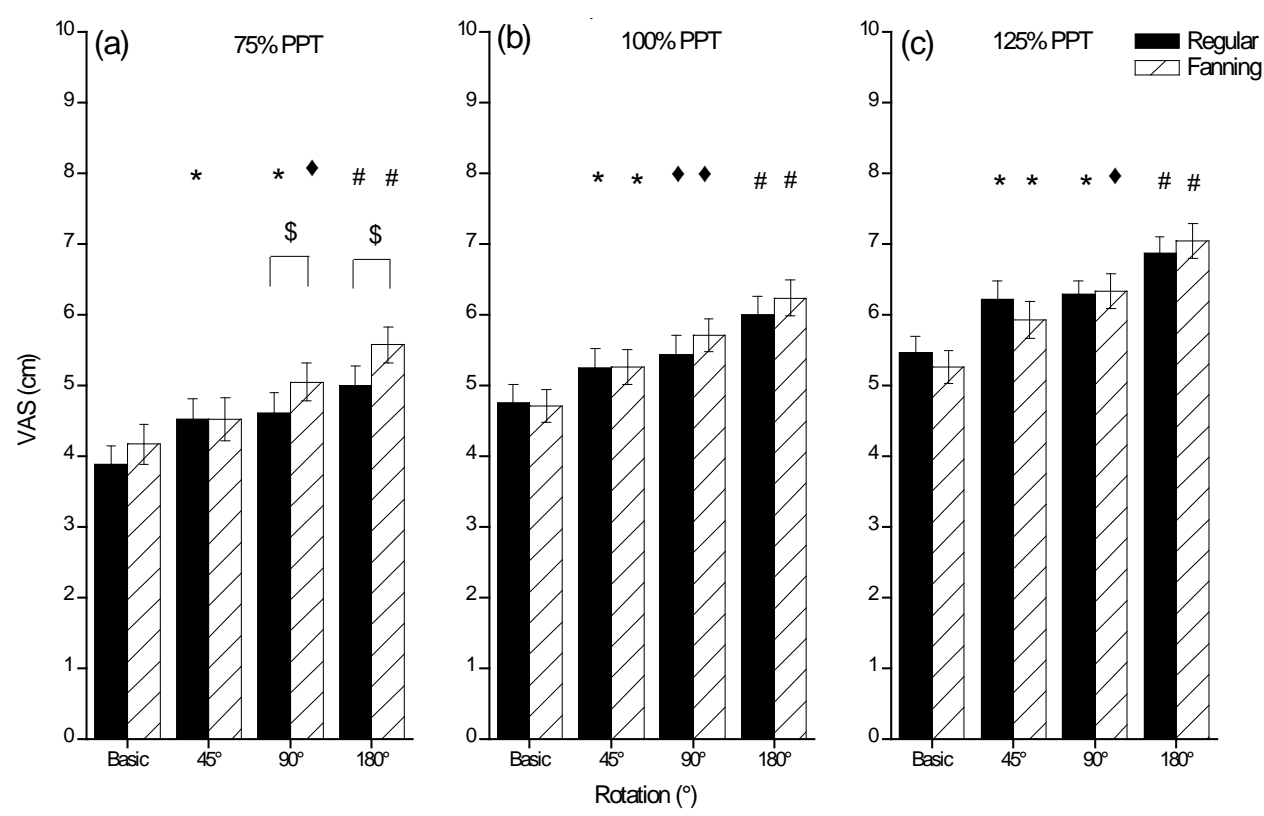

Fig. 9. Mean (+ SEM, N = 24) VAS scores after pressure stimulation with rotational (a-c) paradigm at 75, 100, and 125\% PPT intensities for the regular and fanning probes (Study I). Significantly different VAS scores (BON: P < 0.05) compared with basic $(*)$, basic and $45^{\circ}(\diamond)$, basic, $45^{\circ}$, and $90^{\circ}(\#)$, and between probes (\$) are illustrated. Some of the illustrated post-hoc findings are based on a main effect of feature (i.e. no probe effects) but illustrated identically for each probe (Study I).

\subsection{Probe geometry effect on pressure pain}

Probe geometry effects on pressure-pain has been investigated in previous handheld (Xiong et al., 2011) and computerized algometry studies (Finocchietti et al., 2012). It was demonstrated recently that deep tissue is stimulated with more efficacy via strain when the rounded probes are used (Finocchietti et al., 2012) and it is assumed that semi-spherical property reduces the probeskin contact friction during rotation, unlike the normally used flat probes. It is therefore speculated that the increase in rotational travel angle of the probe combined with the semispherical probe shape is more effectively increasing strain on the deep structures. Such combination of changing angle and reduced contact friction due to roundness is perhaps what is essential to the effectiveness of manual thumb palpation (Degenhardt et al., 2005; Halma et al., 2008; Degenhardt 2009; Degenhardt et al., 2010). However, the hypothesized significantly stronger effect of the fanning probe was only observed at the subthreshold stimulation level for the 90 and 180 degree rotation in Study I (Fig. 9a). 


\subsection{Biaxial stimulation effects on pain perception in NGF-induced muscle hyperalgesia}

In the Study II, previously mentioned biaxial pressure stimulation paradigms from Study I (basic pressure, rotation, radial vibration, axial vibration) with regards to single stimulus configuration were applied randomly at the individual PPT level to right extensor carpi radialis brevis (ECRB) muscle using regular and fanning application probes. This was a double-blind placebo-controlled study where healthy volunteers attended three identical sessions on Day-1, Day+1, and Day+4. Baseline measurements were taken on Day-1 (pre-injection); subsequently $0.4 \mathrm{ml}$ of either NGF or $0.9 \%$ isotonic saline (control) injection was administered in the forearm on Day0; finally, reassessment was repeated on Day +1 and +4 (post-injection). Similarly to Study I, subjects rated their pain perception after each stimulation paradigm. The administration of NGF significantly reduced PPTs in the experimental group after 24 hours, which is in line with the outcomes of the NGF experimental pain model, whereas the maximal VAS scores for the 5-sec stimulation at PPT intensity without axial vibration, radial vibration and rotation was not significantly different among the various days, probes, or groups because the stimulations were always delivered at the PPT level (Fig. 10).

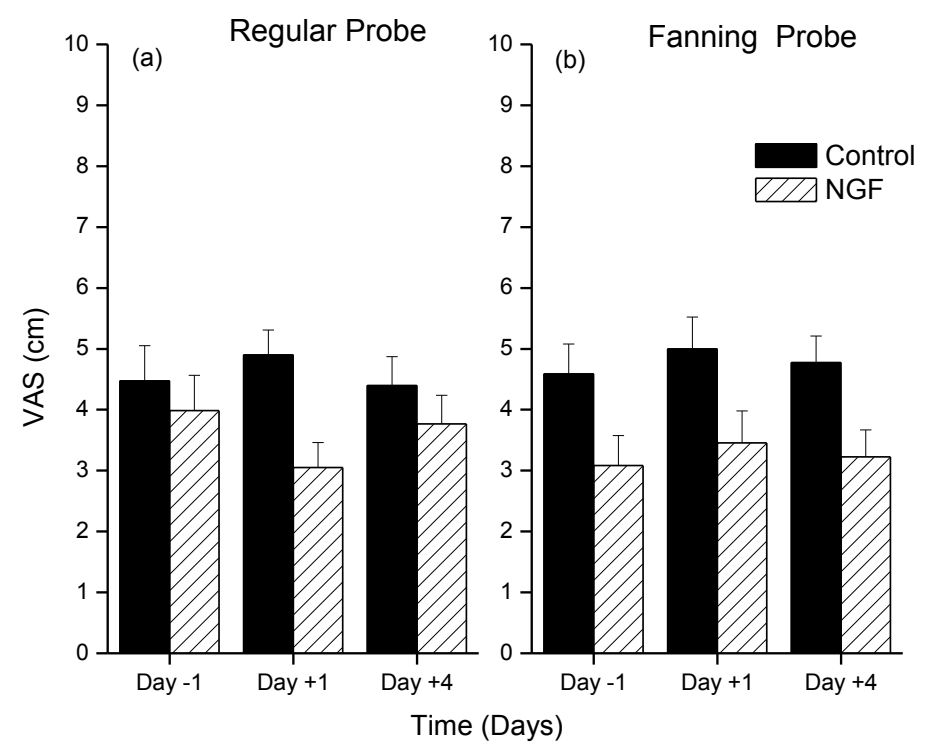

Fig. 10. Mean (+ SEM) VAS scores for basic pressure stimulations at the PPT level (recorded each day) with the regular (a) and fanning (b) probes for the muscle hyperalgesia group (NGF, injection of nerve growth factor) and controls (ISO, injection of isotonic saline) at Day-1, Day+1 and Day+4. No significant differences in VAS scores were found for the probes over the days in either of the groups. 


\subsubsection{Baseline effects of biaxial stimulation on pressure pain}

In order to be able to compare the effects of the novel stimulation paradigms (axial and radial vibration, and rotation) on pain perception in normal (Study I) and hyperalgesic muscle (Study II), Study I data and Study II pre-injection data was normalized with respect to the basic (pressure only) stimulation. The two sets of data obtained in different studies were in concordance: only features (angles) for the rotational paradigm were significantly different among each other, where greater stimulation angle corresponded to greater pain perception (1.6 $\pm 0.1,1.8 \pm 0.2,2.0 \pm 0.2$ for 45,90 , and $180^{\circ}$, respectively). Vibrational frequencies (axial or radial) were perceived at the same pain intensity level regardless of the stimulation frequency (axial: $1.1 \pm 0.1,1.1 \pm 0.1,1.1 \pm 0.1$ as mean of both probes for 15,25 , and $50 \mathrm{~Hz}$, respectively; and radial: $1.6 \pm 0.1,1.6 \pm 0.6,1.5 \pm 0.1$ as mean of both probes for 5,15 , and $25 \mathrm{~Hz}$, respectively).

\subsubsection{Hyperalgesic effects of biaxial stimulation on pressure pain}

As for the post-injection results performed on the normalized data, only rotational paradigm yielded significant and progressively increasing pain perception results with an increasing stimulation angle, which is further enhanced with the fanning probe (Fig. 11). Admittedly, the control group recognized the 180 degree stimulation as distinct relative to the other travel angles (Fig. 11a), but not comparably as much as the NGF group (Fig. 11b). It is evident that rotation is not only able to distinguish among the two groups but also to enhance the pain perception in the NGF group when combined with the fanning probe. It is speculated that this effect is due to the more efficient pressure stimulation where geometric property of the fanning probe (misaligned connection and stimulation axis, Fig. 6) coupled with the dynamic angle progression leads to better recruitment and activation of nociceptors relative to other modalities. The fact that especially the rotational fanning probe was particularly efficient to assess the hyperalgesic muscle tissue further illustrates inclusion of the deep tissue sensitivity when assessing the pain sensitivity with the rotational fanning probe. Thus, the new optimal mechanical stimulation methodology relevant for pressure algometry (pressure combined with controlled rotation plus fanning probe) was demonstrated as pertinent to quantify tenderness in the musculoskeletal structures via standardized biaxial pressure stimulation. 


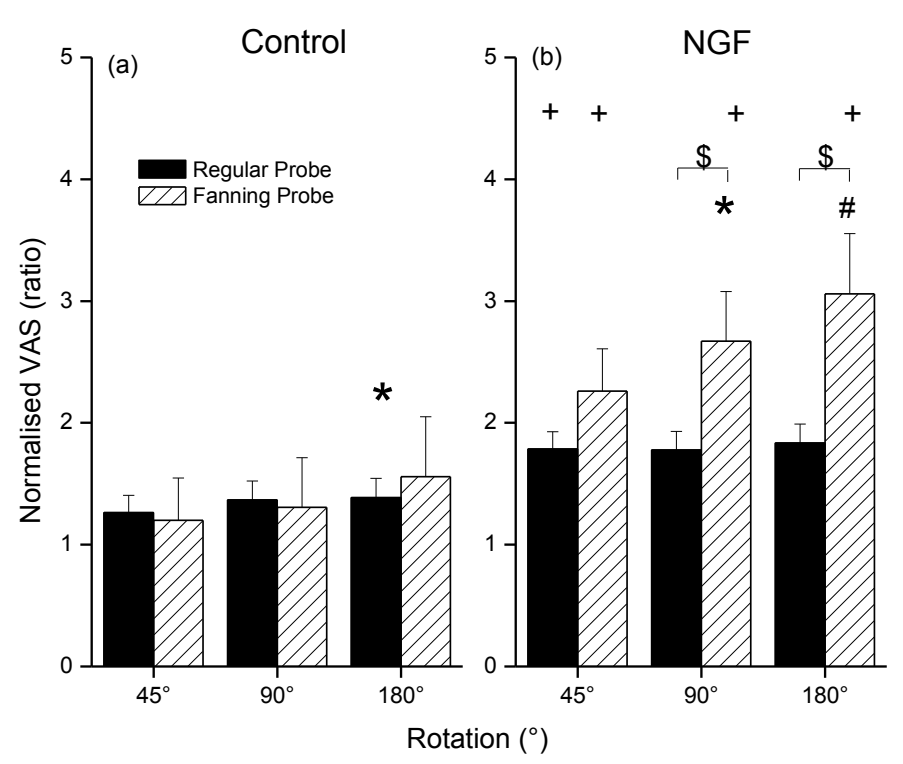

Fig. 11. Post-injection mean (+ SEM) normalised VAS scores for the regular (solid bars) and fanning (white bars) probes for isotonic (ISO) control (a) and NGF (b) groups during rotational stimulation. The VAS scores were averaged among at Day+1 and Day+4 because these measures were not significantly different. VAS scores are normalised by division by the VAS scores from the basic pressure stimulation in the same session. Significantly higher scores compared with $45^{\circ}$ rotations (*, BON: $\mathrm{P}<0.05)$ and compared with $45^{\circ}$ and $90^{\circ}$ rotations (\#, BON: $\mathrm{P}<0.01$ ). Significantly higher scores for the fanning probe compared with the regular probe $(\$, B O N$ : $\mathrm{P}<$ 0.02). Significantly higher scores compared with the control group, for the particular probe and feature combination $(+, \mathrm{BON}: \mathrm{P}<0.05)$. 


\section{$5 \quad$ Reliability and validity of pressure algometry}

Reliability can be thought of as the extent to which a measurement gives results that are consistent (focus on consistency), whereas validity of an assessment is the degree to which it measures what it is supposed to measure (accent on accuracy) (Walker 2011). Thus, a method can be reliable but not necessarily valid. There exist various reliability assessment methods which account for environmental, administrator, equipment, and time related factors among others (Walker 2011). Most of the equipment reliability is assessed through test-retest paradigm, where relative and absolute reliability parameters are the relevant descriptors used. Validity can be assessed by quantifying whether the contesting (new) method measures what it was designed to measure, relative to an already accepted paradigm (golden standard).

Relative reliability is the degree to which relevant scores (e.g. PPT, VAS) maintain their position in a sample over repeated measurements. It represents the proportion of the variance attributable to between-subject variability (subject effect). Relative reliability can be evaluated via intraclass correlation coefficient (ICC) resulting as an outcome between the two trials that can be assessed for the same rater (intra-rater) or among raters (inter-rater) (Weir 2005). Formulas used to calculate ICC depend on the purpose and design of the study, as well as type of measurements taken (Table 1). Values higher than 0.8 are considered to be in "perfect agreement" or "excellent agreement" (Fleiss 1986). Although less robust relative to the ICC, Pearson correlation coefficient can be used as relative reliability descriptor as well. The ICC has the same drawback as the Pearson's "R", i.e. it is affected by the heterogeneity of the sample: if the variance between subjects is sufficiently high, then reliability will inevitably appear to be high (Atkinson and Nevill 1998).

Table 1. ICC (model, form) types, (Weir 2005).

\begin{tabular}{|c|l|}
\hline ICC Type & Description \\
\hline ICC $(1,1)$ & $\begin{array}{l}\text { Each subject is assessed by a different set of randomly selected raters, and the reliability is } \\
\text { calculated from a single measurement. Uncommonly used in clinical reliability studies. }\end{array}$ \\
\hline ICC $(1, \mathrm{k})$ & As above, but reliability is calculated by taking an average of the k raters' measurements. \\
\hline ICC $(2,1)$ & $\begin{array}{l}\text { Each subject is measured by each rater, and raters are considered representative of a larger } \\
\text { population of similar raters. Reliability calculated from a single measurement. }\end{array}$ \\
\hline ICC $(2, \mathrm{k})$ & As above, but reliability is calculated by taking an average of the k raters' measurements. \\
\hline ICC $(3,1)$ & $\begin{array}{l}\text { Each subject is assessed by each rater, but the raters are the only raters of interest. } \\
\text { Reliability calculated from a single measurement. }\end{array}$ \\
\hline ICC $(3, \mathrm{k})$ & As above, but reliability is calculated by taking an average of the k raters' measurements. \\
\hline
\end{tabular}


Contrary, absolute reliability is the degree to which repeated measures vary for individual measurements. It can be used to compare two different methodologies or devices (assessing validity) as well as to evaluate test-retest reliability of the same outcome measure. Absolute reliability can be examined via systematic error of measurement (quantifies the precision of individual scores on a test), coefficient of variation ( $\mathrm{CoV}$ expresses a standard deviation as a proportion of the mean (Atkinson and Nevill 1998)), and by making the Bland-Altman plot depicting limits of agreement (LoA) between test and retest procedures, where LoA provides the range within which most of the differences (95\%) between measurements are expected to lie (Atkinson and Nevill 1998; Bland and Altman 1999).

\subsection{Variability of manual pressure algometry}

Numerous studies have investigated both between- and within-examiner variability of handheld pressure algometry. This is not surprising given that most used deep tissue pressure-pain quantification method in the classical QST battery is handheld rather than computerized algometry for the reasons outlined in Chapter 2. Several studies showed that there is a significant and good inter- and intra-rater correlation (ICC $(3,1)>0.75)$ in a vast majority of the assessed sites (Chung et al., 1992; Antonaci et al., 1998), whereas another study demonstrated that examiner anticipation might affect the outcome measure (Ohrbach et al., 1998).

More recent studies have shown that handheld algometry demonstrates high ICC values (ICC $(3, \mathrm{k})>0.9)$ assessed in human muscle (Jones et al., 2007), but tends to overestimate the measurement as the pressure progresses to the higher values (Vaughan et al., 2007; Fingleton et al., 2014). It was also revealed that the reliability of the measurement improves with the examiner training (Chesterton et al., 2007) and especially if one examiner would perform all measurements over consecutive days for instance (Nussbaum and Downes 1998; Jones et al., 2007). The method was also demonstrated as reliable to detect hypersensitivity in the knee joint tissue (Wylde et al., 2011) as well as in tender points (Jaeger and Reeves 1986; Persson et al., 2004). 


\subsection{Computerized stimulation reliability}

\subsubsection{Pressure pain threshold reliability}

Computerized pressure algometry (Polianskis et al., 2002b; Nie et al., 2005; Dagtekin et al., 2007; Xiong et al., 2010; Kruger et al., 2011; Zimkowski et al., 2011; Harte et al., 2013; Koo et al., 2013) offers standardized ways of assessing pain sensitivity in patients by removing rater variability characteristical for portable handheld algometers (Additional Tables, Table A). Biaxial computerized algometry excludes manual researcher's involvement and therefore should contribute to higher standardization and reliability outcomes.

Only two studies (Xiong et al., 2011; Koo et al., 2013) out of the computerized algometers mentioned above assessed relative reliability of such devices. It is speculated that this is mainly due to limited availability and almost exclusive presence of automated stimulators in the research setting relative to the market. PPTs assessed via biaxial moving coil pressure algometer yielded high intraclass correlation coefficient $\left(\operatorname{ICC}(3, \mathrm{k})_{\text {ave, biaxial }}=0.94\right)$ and this value for the biaxial computer-controlled algometer has not yet been reported. Study I additionally yielded handheld ICC $(3, \mathrm{k})_{\mathrm{ave}}$, handheld of 0.945 . In other studies, unidirectional (linear) computerized algometers using indentation rather than force-feedback control reported to have ICC > 0.8 (Xiong et al., 2011) and somewhat lower relative reliability compared to the handheld one used in the same experiment $\left(\operatorname{ICC}(3,1)_{\text {handheld }}=0.91, \operatorname{ICC}(3,1)_{\text {unidrectional }}=0.87\right)$ (Koo et al., 2013).

One other study in addition to Study I of this $\mathrm{PhD}$ project assessed absolute reliability of the computerized algometry using LoA method. Absolute reliability, in particular limits of agreement, is used when the new method (computerized algometry) challenges the traditionally accepted one (handheld algometry). In that light, previous studies used LoA to make comparisons among hand-held, computerized pneumatic, and computer-controlled gear-driven algometer to assess whether the new method is up to par with the previous ones (Table A) (Dagtekin et al., 2007). Test-retest reliability of the PPTs for the biaxial algometers has not been reported before using LoA. In the Study I, biaxial LoA and handheld LoA have demonstrated comparable 95\% confidence intervals and systematic biases ( $\mathrm{LoA}$ ave, handheld $=[-157.2158 .2]$ $\mathrm{kPa}, \mathrm{BIAS}$ abs, ave, handheld $=7 \mathrm{kPa} ; \operatorname{LoA}_{\text {ave, biaxial }}=[-182.1160 .0] \mathrm{kPa}, \mathrm{BIAS}$ abs, ave, biaxial $=11.1$ $\mathrm{kPa}$ ) suggesting validity of the accepted method (manual algometry) and the repeatability of the challenging method (biaxial algometry). 


\subsubsection{Pain response variability}

Study I evaluated the VAS reliability through test-retest procedure for axial vibration, radial vibration, as well as for rotation on top of the fundamental pressure. The three biaxial pressure stimulation paradigms yielded combined $\operatorname{ICC}(3, \mathrm{k})$ of 0.77 , which represents a "substantial agreement" (Fleiss 1986), and with similar outcomes when analyzed separately (Adnadjevic and Graven-Nielsen 2013). The absolute reliability reflected in the limits of agreement showed that $95 \%$ of the VAS differences for all of the paradigms rested in the LoA $=\left[\begin{array}{ll}-2.8 & 2.7\end{array}\right] \mathrm{cm}$ interval with an approximate $0 \mathrm{~cm}$ bias, which is reflected in the uniform distribution of data in Fig. 12. Such a centered interval suggests that approximately equal number of values were higher in magnitude by VAS $=2.75 \mathrm{~cm}$ the first time than the second time, and vice versa. In addition, the typical percentage error expressed as the coefficient of variation revealed a $16 \%$ extent in VAS score variability relative to the mean of the outcome population.
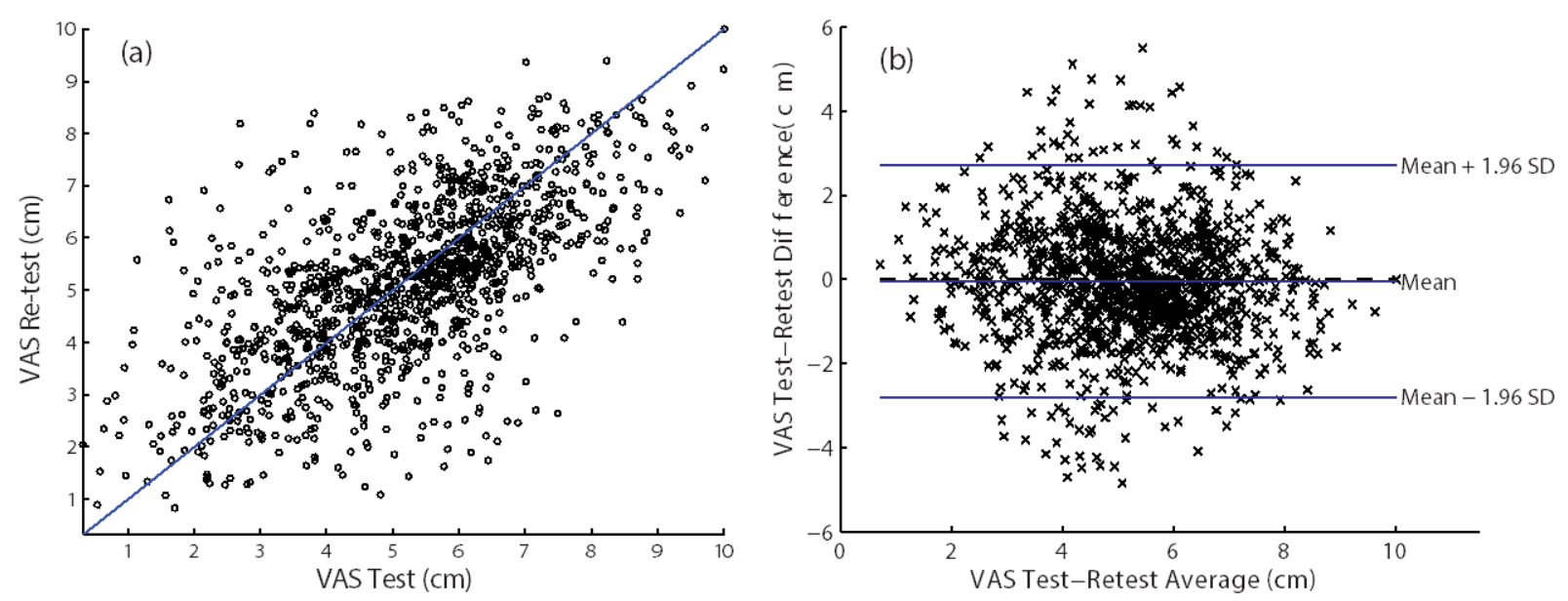

Fig. 12. VAS scale test-retest Scatter (a) and Bland-Altman (b) plots are shown for $\mathrm{N}=1248$ paired VAS scores (24 subjects, 52 repeated measures). Test-retest points would coincide perfectly if they did not deviate from the $45^{\circ}$ line in panel (a). Differences on two test occasions are plotted against respected averages in panel (b), where confidence interval lines are drawn and expressed as Mean $\pm 1.96 \mathrm{SD}$. The systematic bias line representing the mean of the differences between the two test occasions is drawn relative to the dashed one representing $0 \mathrm{~cm}$ bias (Study I). 
Whether abovementioned reliability descriptors are clinically/research-wise acceptable is to be determined by the intended use of the equipment i.e. what kind of stimulation it applies and to which purpose, as well as what means it uses to assess the outcome. Visual analogue scales correlate highly with pain assessed via verbal and numerical rating scales (Ohnhaus and Adler 1975; Ekblom and Hansson 1988; Bijur et al., 2003) but lack in representing multidimensionality of pain. On the other hand, Descriptor Differential Scale developed by Gracely's group to assess separately intensity and unpleasantness dimensions of pain, was shown to be more sensitive to pharmacological interventions (Gracely et al., 1978; Gracely et al., 1979; Atkinson et al., 1998) as well as to have high reliability and internal consistency as a clinical pain measure (Gracely and Kwilosz 1988).

Finally, a certain amount of caution needs to be exercised when stating that the reliability shows substantial agreement since this finding is pertinent to this particular experimental design and subject population. For instance, the test-retest ICC reliability of the paper-based VAS pain scores in low back pain patients were reported to reside in the 0.66-0.76 range, where the highest level of agreement was found between the two observations with the least intervening time (Miller and Ferris 1993; Roach et al., 1997). It is worth noting that variation in reliability these studies have shown could be related to the actual changes of the pain intensities, whereas Study I was conducted on healthy individuals where variability in pain intensity should be less prone to changes. 


\section{Influences of biaxial repeated stimulation on pressure evoked pain}

Temporal summation of pain due to recurrent pressure stimulation can provide insights into sensitization levels of the central nervous system. Due to the novelties associated with the biaxial algometer such as stronger, faster, and more precise stimulation (Section 3.2) which may better approximate neuronal wind-up phenomenon (Mendell 1966) found in animals (a correlate of the temporal summation of pain in humans (Arendt-Nielsen et al., 1994; Arendt-Nielsen and Graven-Nielsen 2008)), it was hypothesized these new stimulation techniques would show more efficacy in inducing temporal summation than conventional pressure stimulus configuration (2 second inter-stimulus interval (ISI)). Thus, Study III examined effects of longer stimulus duration relative to shorter ones for the same frequency, higher stimulation frequencies compared with lower ones for the same stimulus duration, as well as effects of added rotation with the fanning probe in contrast to the regular non-rotating probe.

\subsection{Raw VAS scores - First pulse, Max VAS, and VAS-time area}

The average VAS-time scores for 6 rotational and non-rotational stimulation paradigms shown time and probe differences in Fig. 13. First pulse stimulation effect (Table 2) was higher for rotation compared with non-rotation $(2.8 \pm 0.3$ vs. $2.3 \pm 0.3 \mathrm{~cm})$, and higher for slower frequencies relative to the faster ones $(3.1 \pm 0.3,2.6 \pm 0.3$, and $1.9 \pm 0.2 \mathrm{~cm}$, for $0.5,1$, and 1.5 $\mathrm{Hz}$, respectively.

Table 2. VAS scores in $\mathrm{cm}$ for the $1^{\text {st }}$ pulse in the15-pulse stimulation scheme (Mean \pm SEM) per paradigm.

\begin{tabular}{|c|l|c|c|c|}
\hline Pulse duration & Rotation & \multicolumn{1}{|c|}{$\mathbf{1 . 5} \mathbf{~ H z}$} & $\mathbf{1 ~ H z}$ & $\mathbf{0 . 5} \mathbf{~ H z}$ \\
\hline \multirow{2}{*}{$500 \mathrm{~ms}$} & Without & $1.8 \pm 0.3 \mathrm{~cm}$ & $2.4 \pm 0.4 \mathrm{~cm}$ & $3.2 \pm 0.5 \mathrm{~cm}$ \\
\cline { 2 - 5 } & With & $2.2 \pm 0.4 \mathrm{~cm}$ & $2.8 \pm 0.4 \mathrm{~cm}$ & $3.4 \pm 0.5 \mathrm{~cm}$ \\
\hline \multirow{2}{*}{$300 \mathrm{~ms}$} & Without & $1.7 \pm 0.2 \mathrm{~cm}$ & $2.1 \pm 0.2 \mathrm{~cm}$ & $2.7 \pm 0.4 \mathrm{~cm}$ \\
\cline { 2 - 5 } & With & $1.9 \pm 0.3 \mathrm{~cm}$ & $3.0 \pm 0.4 \mathrm{~cm}$ & $3.2 \pm 0.3 \mathrm{~cm}$ \\
\hline
\end{tabular}

Maximum VAS score were higher for $500 \mathrm{~ms}$ than $300 \mathrm{~ms}$ ( $7.2 \pm 0.3$ vs. $6.5 \pm 0.3 \mathrm{~cm})$, rotational than non-rotation $(7.6 \pm 0.3$ vs. $6.0 \pm 0.3 \mathrm{~cm})$, and for 1 and $0.5 \mathrm{~Hz}$ than $1.5 \mathrm{~Hz}(7.0 \pm 0.3$ and 7.0 \pm 0.2 , vs. $6.6 \pm 0.3 \mathrm{~cm}$ ) stimulation. The area under the VAS-time curve (Fig. 13) for rotational stimulation was significantly larger than non-rotational one for all frequencies $(53.9 \pm 3.1,99.6 \pm$ 5.4 , and $199.0 \pm 9.4 \mathrm{~cm} \cdot \mathrm{s}$ vs. $42.2 \pm 3.5,79.7 \pm 5.5$, and $150.7 \pm 9.6 \mathrm{~cm} \cdot \mathrm{s} ; 1.5,1$, and $0.5 \mathrm{~Hz}$, 
respectively). Finally, within the $1.5 \mathrm{~Hz}$ paradigm, $500 \mathrm{~ms}$ stimulation VAS area was significantly larger than the $300 \mathrm{~ms}$ stimulation one $(58.8 \pm 3.8$ vs. $37.3 \pm 2.7 \mathrm{~cm} \cdot \mathrm{s})$. The explanation behind such outcomes is outlined in subsection 5.3.

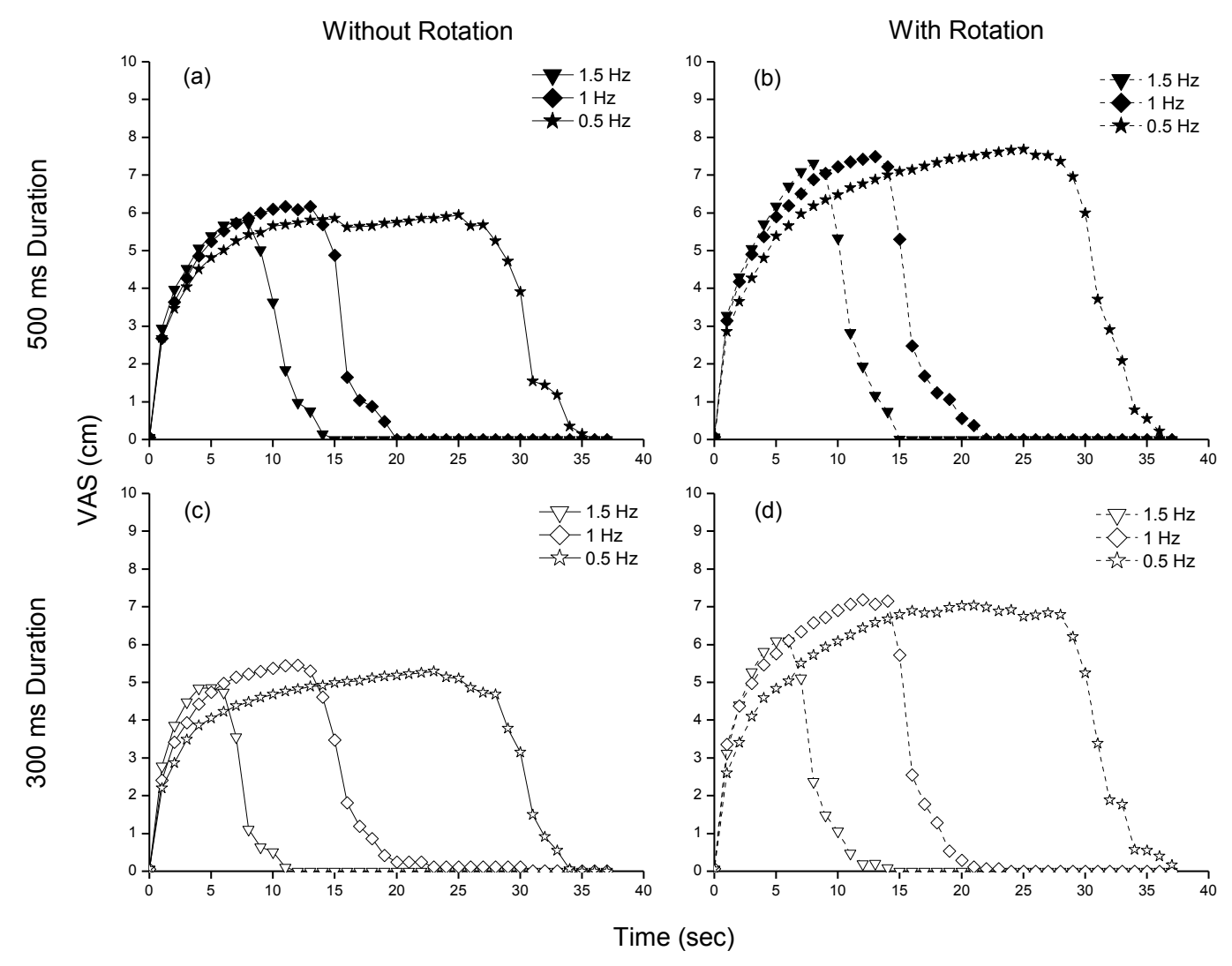

Fig. 13. Raw VAS-time response for different 15-pulse repeated stimulation paradigms

\subsection{Normalized VAS scores - Individual pulse effect and VAS Sum}

The VAS scores normalized to the first stimulation by subtraction are shown in Fig. 14. Analysis on normalized individual pulses showed that each subsequent pulse was higher than the previous one up to pulse 14. Pulse analysis further showed that for $1 \mathrm{~Hz}$ and $0.5 \mathrm{~Hz}$ stimulation frequency, rotational stimulation results in higher normalized VAS scores than no-rotation $(3.2 \pm$ $0.2 \mathrm{~cm}$ vs. $2.8 \pm 0.2 \mathrm{~cm} ; 3.2 \pm 0.2 \mathrm{~cm}$ vs. $2.2 \pm 0.3 \mathrm{~cm}$, respectively). Finally, the VAS score in the non-rotational $1 \mathrm{~Hz}$ stimulation was significantly higher than the $0.5 \mathrm{~Hz}$ non-rotational $(2.8 \pm$ 0.2 vs. $2.2 \pm 0.3 \mathrm{~cm}, \mathrm{BON}: \mathrm{P}<0.03)$. 


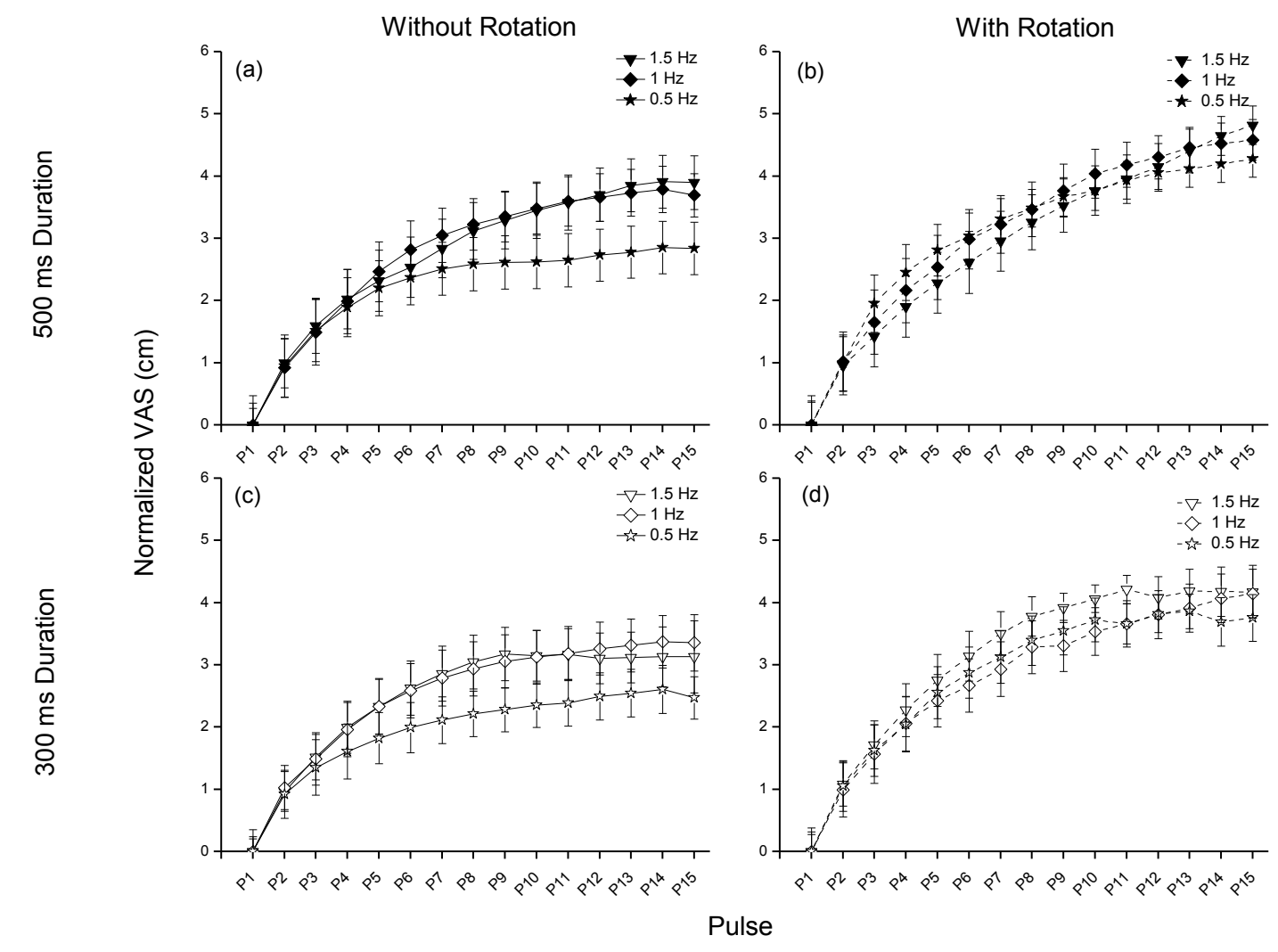

Fig. 14. Mean VAS scores (+ SEM, N=15) normalized via subtraction by the first VAS score for repeated stimulation paradigms at $1.5,1.0$, and $0.5 \mathrm{~Hz}$, for $500 \mathrm{~ms}$ (a, b) and $300 \mathrm{~ms}$ (c, d) stimulus durations and with (b, d) and without (a, c) rotation (Study III).

With regards to the addition of normalized VAS scores (VAS Sum), rotational stimulation had higher summation effect than non-rotational stimulation. Further, non-rotational stimulation of 1 $\mathrm{Hz}$ demonstrated a significantly higher VAS sum than both the $1.5 \mathrm{~Hz}$ and $0.5 \mathrm{~Hz}$ non-rotational stimulation (Fig. 15b).

Study III additionally revealed that within the $1.5 \mathrm{~Hz}$ stimulation, the $500 \mathrm{~ms}$ stimulation resulted in a VAS sum which was significantly higher than the $300 \mathrm{~ms}$ stimulation. Finally, within the $300 \mathrm{~ms}$ stimulus duration paradigm, $1.5 \mathrm{~Hz}$ stimulations resulted in a VAS sum significantly lower than both the $1 \mathrm{~Hz}$ and $0.5 \mathrm{~Hz}$ stimulation (Fig. 15a). 


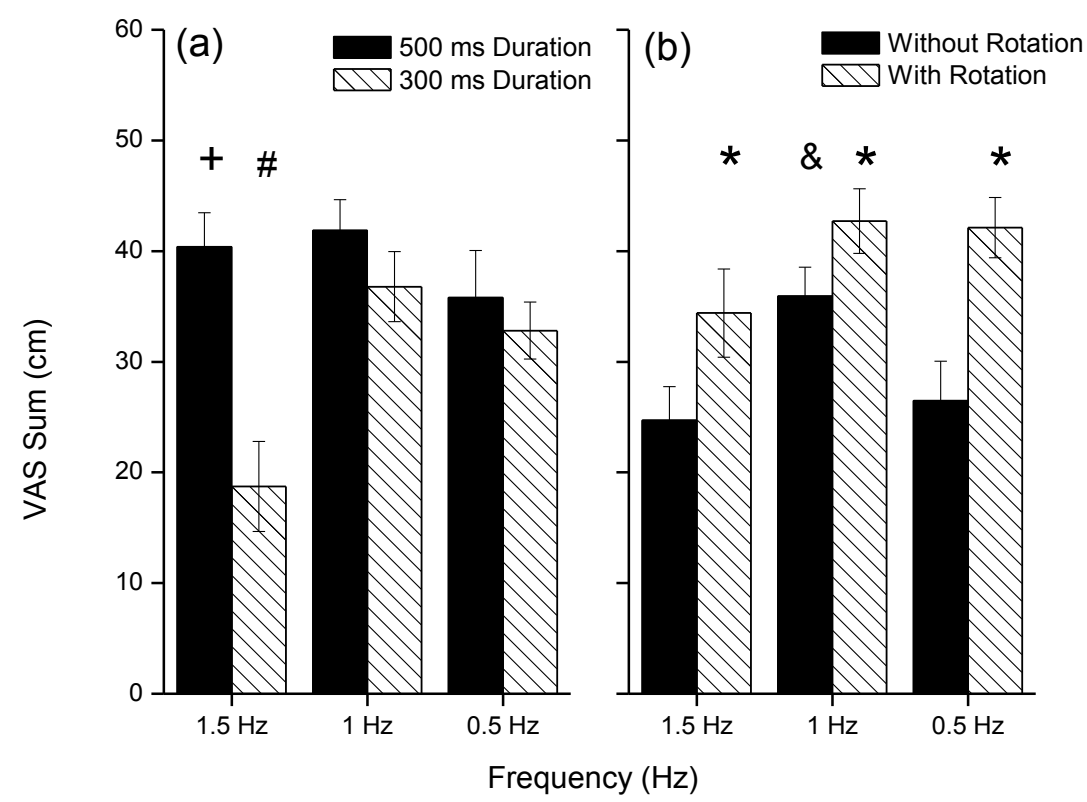

Fig. 15. Mean VAS sum (+ SEM, N=15) is illustrated for stimulus duration*frequency (a) and rotation $*$ frequency (b) interactions. In the (a) panel, plus (+) symbol denotes significantly higher $500 \mathrm{~ms}$ summation within the $1.5 \mathrm{~Hz}$ group, whereas hash (\#) symbol denotes a significantly lower $1.5 \mathrm{~Hz}$ summation score than others within the $300 \mathrm{~ms}$ group (BON: $\mathrm{P}<0.001)$. In panel (b), asterisk (*) symbol denotes a significant difference between rotation and non-rotation scores within the particular frequency, whereas and (\&) symbol denotes a significantly higher nonrotational $1 \mathrm{~Hz}$ summation score relative to other no-rotational cases (BON: $\mathrm{P}<0.01)$. 


\subsection{Relation of frequency, stimulus duration, and rotation to pressure-pain}

\subsubsection{Painfulness of the first stimulus}

Stimulus duration did not have significant effect on the VAS score of the first stimulus delivered at a PPT intensity level. However, the PPT was always determined with $500 \mathrm{~ms}$ stimulus, thus it was anticipated that the $300 \mathrm{~ms}$ stimulation would result in lower VAS outcome. This difference may be accounted due to the diffuse nature of deep tissue pain that is speculatively masking minor differences in stimulus durations for a single pulse. On the other hand, rotation produced higher VAS score of the first pulse relative to non-rotation, which may be attributed to a more efficient deep tissue compression, leading to a better recruitment of receptors. Finally, going from lower to higher stimulation frequencies the pressure sensations decreased, which could be explained with temporal aspects of the stimulus, whereby for the lower frequencies (e.g. $0.5 \mathrm{~Hz}$ ) subjects had more time to update VAS as oppose to the higher frequencies (e.g. $1.5 \mathrm{~Hz}$ ) before the next pulse in the train came along.

Curiously, all of the first pulses resulted in pain-free sensation, although peak VAS scores during repeated stimulation always ended in the painful region (VAS > 5). Contrastingly, another study showed that repeated stimulation of tibialis anterior resulted in the first pulse being painful (Nie et al., 2005). The difference may stem from the way subjects were explained to use the VAS scale, hence the methodological issue. Nie et al. (2005) defined that "no pain" is anchored at VAS $=0$, whereas present study defined "no pain" as VAS $=5$. It is possible that in the Nie et al. (2005) study the subjects moved the scale from the moment stimulation train started regardless of feeling the pressure or pain but actually signaling pain anyway (VAS > 0), whereas in Study III it could be that they moved the scale at the beginning of the pulse train without signaling perceived pain (VAS > 5) while indicating "pressure only" sensation (VAS < 5). However, once the phasic pain threshold was determined, neither of the two studies verified that the painful stimulus actually rested at VAS $=0$ and VAS $=5$, respectively which could be a methodological issue.

\subsubsection{Frequency related temporal summation of pressure pain}

The novelty of Study III rests in adequate pressure stimulation at $1 \mathrm{~Hz}$ or faster frequencies with precisely controlled contact and break duration times which is speculated to better approximate neuronal wind-up phenomenon observed and measured in animal neurophysiology studies. 
Faster frequencies $(1.5 \mathrm{~Hz})$ of repeated stimulation produced smaller effect on temporal summation than moderate to low frequencies $(1-0.5 \mathrm{~Hz})$. This is contrasting the results obtained in the previous studies (Staud et al., 2003; Nie et al., 2005) where smaller inter-stimulus intervals (ISI) (2-3 seconds) evoked more temporal summation of pain relative to ISIs larger than 3 seconds. Namely, sequential stimulation with the shortest ISIs produced higher pain sensation than those with longer ISIs, indicating that temporal summation of deep tissue pain depends on frequency. Traditionally, there is more temporal summation with quicker pressure stimulation of 2 second ISI $(0.5 \mathrm{~Hz})$ relative to ISIs > 3 seconds (Nie et al., 2005). However, it could be that even quicker repeated pressure stimulation of $1.5 \mathrm{~Hz}$ also evokes stimulation of other receptor properties affecting the pain perception. Study I as well as other linear vibration studies (Kakigi and Shibasaki 1992; Weerakkody et al., 2003) showed that vibration has inhibitory potential on perceived pain, indicating that the borderline between fast repeated stimulation and vibration has been detected where frequencies greater than $1 \mathrm{~Hz}$ trigger the inhibitory interaction between simultaneous pressure stimulation of low-threshold mechanoreceptors and nociceptors.

It is worth noting that subjects could have had difficulties rating the perceived pain in the timely manner during $1.5 \mathrm{~Hz}$ repeated stimulation which amounts to 10 seconds in duration, thus creating a result biased in favor of the methodological error. It could be that subjects could not rate the pain adequately, ideally after each stimulus was delivered as they were asked. Potentially pain perception reflected in after-sensation to the recurrent stimulation (Hassler 1976) could have reflected the more pronounced effects at $1.5 \mathrm{~Hz}$ stimulation; however, this was not asked from the subjects to rate during Study III.

\subsubsection{Effects of stimulus duration on the temporal summation of pain}

Temporal summation of pain was more pronounced for 500 than $300 \mathrm{~ms}$ stimulus duration. Within the same recurrence the fact that $500 \mathrm{~ms}$ stimulus duration is more efficient in eliciting pain than $300 \mathrm{~ms}$ stimulation could be attributed to the longer effective contact time with the deep somatic tissue. The difference between the two durations at the end of the 15-pulse train reduced the variability of the VAS scores, where the $200 \mathrm{~ms}$ duration difference revealed the effect it has on pain perception.

It was shown previously that sustained and long mechanical stimulation evokes temporal summation of pain where pain perception tends to worsen with prolonged stimulation (Goddard et al., 2004; Samuelsson et al., 2005; Hori and Kishi 2011). In contrast to this finding, such a 
long input can also lead to pain adaptation due to receptor fatigue in nociceptive thermal (Kojo and Pertovaara 1987; Hollins et al., 2011), electrical (Pette and Vrbova 1992; Cariga et al., 2001; Guyot et al., 2011), and mechanical (Adriaensen et al., 1984) stimulation, where pain thresholds eventually tend to rise. It could be that a balanced repeated stimulation paradigm needs to be practiced to achieve most efficacy i.e. avoiding receptor fatigue due to adaptation but with as long stimulus duration as achievable.

\subsubsection{Effects of fanning probe rotation on the temporal summation of pain}

It was further demonstrated in Study III that fanning probe rotational repeated stimulation was more painful than non-rotational one. The rational for including fanning probe rotation stems from the findings obtained in Study I and II (Chapter 4) where it was argued 1) that the enhanced perception of deep tissue pain evoked by rotational stimuli covering a larger area might be attributed to facilitation caused by potential involvement of spatial summation of pain, and 2) that the fanning probe is more efficient in recruiting nociceptors than the regular probe during rotation.

In Study III, this effect is augmented by even bigger rotational arcs - while the 15-pulse train was delivered, rotational velocity of 0.05 revolutions/sec circled a half, three quarters, and one and a half revolutions for $1.5,1$, and $0.5 \mathrm{~Hz}$ frequencies, respectively. Therefore, the increase in pain sensation may be argued to happen via facilitating effect of spatial summation on temporal summation of pain (Nie et al., 2009) during rotational pulse train. Potential contributions of pain due to effects of skin pinching and twisting are denounced due to round design of the probe.

Remarkably regarding the non-rotational stimulation, 1.5 and $1 \mathrm{~Hz}$ paradigms seemed most appropriate for eliciting temporal summation compared with traditional $0.5 \mathrm{~Hz}$ stimulations (Fig. 14). However during rotational stimulation, the overall temporal summation profile is higher but any frequency effect is washed out. It could be that rotation simply levels out the potency of the frequencies used, indicating that it saturates the pool of nociceptors in the deep somatic tissue. Finally, the profile of perceived pain is steeper for rotation possibly due to better recruitment of mechano-nociceptors during circumferential repeated stimulation paradigm. 


\section{Concluding Remarks}

This $\mathrm{PhD}$ work focused on the development and validation of the new computerized biaxial algometer (Technical Study) as well as on assessing its efficacy to produce distinct pain perception relative to conventional pressure stimulation in healthy and hyperalgesic somatic tissue. The aims were to improve unidirectional algometry in ways leading to reliable stimulation that is closer to the efficacy pertinent to manual palpation, yet via standardized approach (Study I and II). In addition, the setup explored the effects of the fast, precise, and overshoot-free repeated bidirectional stimulation on temporal summation of pain (Study III).

In particular, Study I and II investigated static and dynamic features of the stimulation parameters in order to improve stimulus efficacy. It was shown that the simple alteration in geometrical properties (static approach) of pressure application probe such as misalignment of the connection axis could have an aversive effect on pain perception during rotation. Since the manual palpation is performed both with the down force and circular movements of the thumb, the angular force in conjunction with thrust was used to approximate palpatory motion. Thus, several dynamic stimulation parameters were studied to evaluate pressure-pain sensitivity in different muscles: axial vibration and radial vibration frequencies $(5-50 \mathrm{~Hz})$, and rotation angles $\left(45-180^{\circ}\right)$. Additionally, exploring the efficiency of such a probing system to detect hyperalgesia was tested via NGF-induced muscle hyperalgesia model, where it was discovered that fanning (misaligned axis) probe in conjunction with rotation is better in detecting hyperalgesia than the regular (aligned axis) probe or other modalities. The validation process of aforementioned stimulation parameters was addressed via test-retest paradigm with high relative and absolute reliability outcome parameters.

As for the second aim, bidirectional stimulation parameters confronted the classical approach of performing repeated stimulation (Study III). Since the novel algometer can be controlled in a highly accurate manner (bidirectional positioning, force, velocity), the new methods of pressure application approximated better real temporal summation as observed and measured in neurophysiology. Thus, the classical method of evoking temporal summation with pressure via $0.5 \mathrm{~Hz}$ frequency was challenged against higher frequencies $(1,1.5 \mathrm{~Hz})$, different stimulus durations in the train, and presence of rotation, where it was showed that optimum of $500 \mathrm{~ms}$ stimulus duration combined with fanning probe rotation produces most temporal summation of pain. 
Stimulation parameters examined during this $\mathrm{PhD}$ work such as fanning probe rotation and precise control of the stimulus duration, intensity, and frequency could be pivotal in diagnosing various pain disorders (e.g. systemic hypersensitivity to stimulations that are not usually painful in healthy population). By the means of measuring temporal summation of pain in a subject through precise bidirectional repeated stimulation it could be possible to determine if the subject suffers from central nervous system sensitization, which is important for paving the proper path for patient treatment. Further, these stimulation parameters could complement methods used for detecting tender spots in muscular tissue in a more robust and standardized manner, which is important for quantifying the level of muscle soreness during rehabilitation for instance.

Finally, the current embodiment of the biaxial pressure algometer (sheer setup size, weight, desktop PC operability) is suited for a laboratory setting but it would be highly relevant to develop and validate a portable version of the setup. Such a portable device should additionally allow for conduction of clinical studies in patient population both in hospitals and homes due to increased mobility of the setup. This could potentially lead to the development of the standardized marketable product that complements the quantitative sensory testing (QST) battery. 


\section{Dansk Sammenfatning}

Dybe smerter I bevægeapparatet er et meget hyppigt symptom, som har stor betydning for den enkelte patient og som kan betyde en alvorlig forringelse af livskvaliteten. Nociceptorer er såkaldte smertereceptorer, der findes i hud, muskler, sener og knogle vævet. Hvis vævet udsættes for langvarig eller gentagen inflammation, ændres følsomheden af disse nociceptorer, så de er mere følsomme over for stimuli. Sensibilisering er sandsynligvis den vigtigste mekanisme bag smerter ved kroniske smerter i bevægeapparatet. Studiets formål er at skabe metoder til vurdering af smerte overfølsomhed i dybt væv ved hjælp af nye mekaniske stimulerings teknikker.

Denne ph.d.-afhandling har fokus på udvikling og validering af et nyt computerstyret biaksialt algometer (teknisk studie) samt på vurdering af algometrets evne til at producere en distinkt smerteopfattelse i forhold til konventionel trykstimulation i rask og hyperalgesisk somatisk væv. Formålet var at forbedre envejsalgometri, således at der opnås en pålidelig stimulation, som er nærmere virkningsgraden af manuel palpering, men ved hjælp af en standardiseret tilgang (Studie I og II). Derudover undersøges effekten af hurtig, præcis og ikke-overdimensioneret gentagen bidirektional stimulation på temporal smertesummation (Studie III).

Studie I og II har særlig fokus på statiske og dynamiske funktioner/detaljer i stimulationsparametrene til forbedring af stimulusvirkningen. Det viser sig, at en simpel ændring i de geometriske egenskaber (statisk tilgang) af trykpåføringsproben som fejlindstilling af forbindelsesaksen kan have en aversiv effekt på smerteopfattelsen under rotationer. Da manuel palpering udføres med både nedadgående tryk og cirkulære bevægelser af tommelfingeren, anvendtes den angulære kraft i forening med trykkraften til at tilnærme palpations $\neg$ bevægelser. Således blev forskellige dynamiske stimulationsparametre undersøgt for at vurdere tryksmertefølsomhed i forskellige muskler: Aksiale og radiale vibrationsfrekvenser $(5-50 \mathrm{~Hz})$ og rotationsvinkler $\left(45-180^{\circ}\right)$. Endvidere unders $\emptyset$ gtes probesystemets evne til at påvise hyperalgesi ved hjælp af en NGF-induceret muskelhyperalgesimodel, hvor det viste sig at en vifteformet (skævtsiddende akse) probe i forening med rotation var bedre til at detektere hyperalgesi end en regulær (afrettet) probe eller andre metoder. Valideringen af ovennævnte stimulationsparametre blev gennemført ved hjælp af et test-retest paradigme med høje relative og absolutte drifts $\neg$ sikkerheds $\neg$ resultatparametre. 
Til belysning af det andet formål anvendtes bidirektionale stimulationsparametre sammenlignet med den klassiske tilgang med udførelse af gentagne stimulationer (Studie III). Da det nye algometer kan kontrolleres på en meget præcis måde (bidirektional placering, kraft, hastighed), kunne de nye metoder til trykpåføring bedre tilnærmes reel temporal summation end påvist og målt inden for neurofysiologi. Således blev den klassiske metode til fremkaldelse af temoral summation med et tryk på $0,5 \mathrm{~Hz}$ frekvens udfordret med højere frekvenser $(1,1,5 \mathrm{~Hz})$, forskellige stimulusvarigheder $\mathrm{i}$ toget samt anvendelse af rotationer, hvor det viste sig, at optimum af $500 \mathrm{~ms}$ stimulusvarighed kombineret med vifteprobe-rotationer producerer den højeste grad af temporal summation.

De stimulationsparametre, som blev unders $\emptyset$ gt i denne ph.d.-afhandling, f.eks. vifteproberotation og præcis kontrol af stimulusvarighed, intensitet og frekvens kunne være afgørende i diagnosticeringen af forskellige smertelidelser (f.eks. systemisk hypersensitivitet til stimulationer, som raske personer ikke normalt opfatter som smertefulde). Ved at måle temporal smertesummation på en forsøgsperson ved hjælp af præcis bidirektional gentagen stimulation vil det være muligt at klarlægge, om personen lider af sensibilisering af centralnervesystemet, hvilket er vigtigt for at kunne finde den rette behandling af patienten. Endvidere kunne disse stimulationsparametre komplementere eksisterende metoder til at påvise $\emptyset$ mme punkter i muskelvæv på en mere robust og standardiseret måde, hvilket er vigtigt for at kunne kvantificere niveauet af muskelømhed f.eks. under rehabilitering.

Den nuværende form af det biaksiale trykalgometer (størrelse, vægt, tilslutning til desktopcomputer) er passende til et laboratoriemæssigt set-up, men det ville være højst relevant at udvikle og validere en bærbar model af apparatet. En sådan bærbar enhed ville, grundet den forbedrede mobilitet af apparaturet, kunne muliggøre udførelse af kliniske studier på patientgrupper både på hospitaler og i hjemmet. Dette kunne potentielt føre til udvikling af et standardiseret markedsparat produkt, som vil kunne komplementere testbatteriet, der anvendes til kvantitative sensoriske tests (QST). 
9 Additional Tables 
Table A. Chronological overview of recent computer-controlled pressure algometry devices (cuff and point pressure)

\begin{tabular}{|c|c|c|c|c|}
\hline Reference & Driving Mechanism & Assessment Site & $\begin{array}{l}\text { Stimulation } \\
\text { Abilities }\end{array}$ & $\begin{array}{l}\text { Validity and/ or } \\
\text { Reliability }\end{array}$ \\
\hline $\begin{array}{l}\text { (Polianskis et al., } \\
\text { 2001) }\end{array}$ & $\begin{array}{l}\text { Pneumatically driven } \\
\text { cuff algometer, single } \\
\text { or double chamber, } \\
11 \text { or } 13 \mathrm{~cm} \text { wide. }\end{array}$ & $\begin{array}{l}\text { One extremity at the time; } \\
\text { electronic VAS and pressure } \\
\text { force recordings. }\end{array}$ & $\begin{array}{l}\text { Pressure rate; } \\
\text { constant pressure; } \\
\text { repeated and } \\
\text { spatial stimulation. }\end{array}$ & $\mathrm{n} / \mathrm{a}$ \\
\hline $\begin{array}{l}\text { (Weerakkody et al., } \\
\text { 2003) }\end{array}$ & $\begin{array}{l}\text { Moving coil, } \\
\text { unidirectional device. }\end{array}$ & $\begin{array}{l}\text { Single point bodily } \\
\text { stimulation. VAS and } \\
\text { pressure recordings. }\end{array}$ & $\begin{array}{l}\text { Constant pressure } \\
\text { stimulation; } \\
\text { vibration. }\end{array}$ & $\mathrm{n} / \mathrm{a}$ \\
\hline $\begin{array}{l}\text { (Graven-Nielsen et } \\
\text { al., 2004) }\end{array}$ & $\begin{array}{l}\text { Gear-driven point } \\
\text { pressure algometer, } \\
\text { computer controlled } \\
\text { XY plane } \\
\text { positioning. }\end{array}$ & $\begin{array}{l}\text { Single or a matrix of points } \\
\text { (max 10x10) bodily } \\
\text { stimulation; electronic VAS } \\
\text { and pressure force } \\
\text { recordings. }\end{array}$ & $\begin{array}{l}\text { Pressure rate; } \\
\text { constant pressure; } \\
\text { repeated and } \\
\text { spatial sequential } \\
\text { stimulation. }\end{array}$ & $\mathrm{n} / \mathrm{a}$ \\
\hline $\begin{array}{l}\text { (Jespersen et al., } \\
\text { 2007) }\end{array}$ & $\begin{array}{l}\text { Pneumatically driven } \\
\text { cuff algometer, } \\
\text { double-chambered } \\
(13 \times 61 \mathrm{~cm}) .\end{array}$ & $\begin{array}{l}\text { One extremity at the time; } \\
\text { electronic VAS and pressure } \\
\text { force recordings. }\end{array}$ & $\begin{array}{l}\text { Pressure rate; } \\
\text { spatial stimulation. }\end{array}$ & $\mathrm{n} / \mathrm{a}$ \\
\hline $\begin{array}{l}\text { (Dagtekin et al., } \\
\text { 2007) }\end{array}$ & $\begin{array}{l}\text { Electromechanically } \\
\text { driven point pressure } \\
\text { algometer. }\end{array}$ & $\begin{array}{l}\text { Single point, thumb } \\
\text { stimulation. }\end{array}$ & $\begin{array}{l}\text { Increasing } \\
\text { stimulation; } \\
\text { constant } \\
\text { stimulation; step- } \\
\text { wise stimulation. }\end{array}$ & $\begin{array}{l}\text { Absolute reliability } \\
\text { assessed against } \\
\text { handheld and pneumatic } \\
\text { algometer in clinical } \\
\text { studies. }\end{array}$ \\
\hline $\begin{array}{l}\text { (Xiong et al., 2010; } \\
\text { Xiong et al., 2011) }\end{array}$ & $\begin{array}{l}200 \text { step/revolution } \\
\text { stepper motor; } \\
\text { Indentation rate } \\
\text { controlled device. }\end{array}$ & $\begin{array}{l}\text { Single point, sole of the foot } \\
\text { stimulation. }\end{array}$ & $\begin{array}{l}\text { Indentation rate; } \\
\text { indentation } \\
\text { direction from } 0^{\circ} \\
\text { to } 360^{\circ}\end{array}$ & $\begin{array}{l}\text { Relative reliability } \\
\text { assessed against itself in } \\
\text { basic research studies. }\end{array}$ \\
\hline
\end{tabular}

\footnotetext{
${ }^{1}$ Abilities are based on the presented protocol for the particular paper
} 


\begin{tabular}{|c|c|c|c|c|}
\hline $\begin{array}{l}\text { (Zimkowski et al., } \\
\text { 2011) }\end{array}$ & $\begin{array}{l}\text { Pneumatically driven } \\
\text { point pressure } \\
\text { algometer. }\end{array}$ & $\begin{array}{l}\text { Single point bodily } \\
\text { stimulation; ECG, pulse } \\
\text { oximetry, blood pressure, } \\
\text { VAS and force recordings. }\end{array}$ & $\begin{array}{l}\text { Pressure rate; } \\
\text { constant pressure. }\end{array}$ & $\mathrm{n} / \mathrm{a}$ \\
\hline $\begin{array}{l}\text { (Adnadjevic and } \\
\text { Graven-Nielsen } \\
\text { 2012) }\end{array}$ & $\begin{array}{l}\text { Moving coil } \\
\text { bidirectional }\left(\mathrm{F}_{\mathrm{Z}} \text {, }\right. \\
\left.\mathrm{M}_{\mathrm{Z}}\right) \text {, point pressure } \\
\text { algometer; } \mathrm{X}- \\
\text { direction manual } \\
\text { positioning. }\end{array}$ & $\begin{array}{l}\text { Single point bodily } \\
\text { stimulation; electronic VAS } \\
\text { and pressure force } \\
\text { recordings. }\end{array}$ & $\begin{array}{l}\text { Pressure rate; } \\
\text { constant pressure; } \\
\text { repeated; step-wise } \\
\text { stimulation; linear } \\
\text { and radial } \\
\text { vibration; rotation. }\end{array}$ & $\begin{array}{l}\text { Absolute and relative } \\
\text { reliability assessed } \\
\text { against itself and } \\
\text { validated against } \\
\text { handheld algometry in } \\
\text { basic research studies. }\end{array}$ \\
\hline (Harte et al., 2013) & $\begin{array}{l}\text { Gear-driven, two- } \\
\text { piece, point pressure } \\
\text { algometer. }\end{array}$ & $\begin{array}{l}\text { Single point stimulation, one } \\
\text { or both thumbs; VAS and } \\
\text { pressure force recordings. }\end{array}$ & $\begin{array}{l}\text { Differential } \\
\text { stimulation; } \\
\text { pressure rate; } \\
\text { constant pressure; } \\
\text { step-wise and } \\
\text { repeated } \\
\text { stimulation. }\end{array}$ & $\begin{array}{l}\text { Validity assessed in FM } \\
\text { patients and healthy } \\
\text { controls against handheld } \\
\text { algometer. }\end{array}$ \\
\hline (Izumi et al., 2013) & $\begin{array}{l}\text { Pneumatically driven } \\
\text { cuff algometer, single } \\
\text { or double chamber, } \\
11 \text { or } 13 \mathrm{~cm} \text { wide. }\end{array}$ & $\begin{array}{l}\text { Multiple extremities; } \\
\text { electronic VAS and pressure } \\
\text { force recordings. }\end{array}$ & $\begin{array}{l}\text { Differential } \\
\text { stimulation; } \\
\text { pressure rate; } \\
\text { constant pressure; } \\
\text { repeated } \\
\text { stimulation; spatial } \\
\text { stimulation. } \\
\end{array}$ & $\begin{array}{l}\text { Relative reliability } \\
\text { assessed against itself } \\
\text { and handheld algometry } \\
\text { in basic research studies. }\end{array}$ \\
\hline (Koo et al., 2013) & $\begin{array}{l}\text { Gear-driven point } \\
\text { pressure algometer; } \\
\text { Indentation rate } \\
\text { controlled device; X- } \\
\text { direction manual } \\
\text { positioning. }\end{array}$ & $\begin{array}{l}\text { Single point bodily } \\
\text { stimulation. }\end{array}$ & $\begin{array}{l}\text { Indentation rate; } \\
\text { pressure force } \\
\text { recordings. }\end{array}$ & $\begin{array}{l}\text { Absolute and relative } \\
\text { reliability assessed } \\
\text { against itself and } \\
\text { handheld algometry in } \\
\text { basic research studies. }\end{array}$ \\
\hline
\end{tabular}




\section{References}

Adnadjevic D., Degenhardt B., Graven-Nielsen T. Biaxial pressure stimulation is more efficient for assessment of muscle pain sensitivity compared with standard pressure algometry Unpublished.; 2013a.

Adnadjevic D. and Graven-Nielsen T. (2012). Moving coil pressure algometer produces consistent force gradient and repeated stimulation. Conf Proc IEEE Eng Med Biol Soc 2012, 6591-6594.

Adnadjevic D. and Graven-Nielsen T.Reliable vibration stimulation combined with pressure algometry. Abstract Book of the 8th Congress of the European Federation of IASP Chapters (EFIC) Florence, Italy: European Pain Federation EFIC; 2013; 1090.

Adnadjevic D., Lorrain T., Graven-Nielsen T. (2013b). Safety system for moving coil pressure algometer. Conf Proc IEEE Eng Med Biol Soc 2013, 5356-5359.

Adriaensen H., Gybels J., Handwerker H.O., Van Hees J. (1984). Nociceptor discharges and sensations due to prolonged noxious mechanical stimulation--a paradox. Hum Neurobiol 3, 53-58.

Ahn B., Kim Y., Oh C.K., Kim J. (2012). Robotic palpation and mechanical property characterization for abnormal tissue localization. Med Biol Eng Comput 50, 961-971.

Aminian-Far A., Hadian M.R., Olyaei G., Talebian S., Bakhtiary A.H. (2011). Whole-body vibration and the prevention and treatment of delayed-onset muscle soreness. J Athl Train 46, 43-49.

Amris K., Jespersen A., Bliddal H. (2010). Self-reported somatosensory symptoms of neuropathic pain in fibromyalgia and chronic widespread pain correlate with tender point count and pressure-pain thresholds. Pain 151, 664-669.

Andrew D. and Greenspan J.D. (1999). Mechanical and heat sensitization of cutaneous nociceptors after peripheral inflammation in the rat. J Neurophysiol 82, 2649-2656.

Antonaci F., Sand T., Lucas G.A. (1998). Pressure algometry in healthy subjects: inter-examiner variability. Scand J Rehabil Med 30, 3-8.

Arendt-Nielsen L., Brennum J., Sindrup S., Bak P. (1994). Electrophysiological and psychophysical quantification of temporal summation in the human nociceptive system. Eur J Appl Physiol Occup Physiol 68, 266-273.

Arendt-Nielsen L. and Graven-Nielsen T. (2008). Translational Aspects of Musculoskeletal Pain: From Animals to Patients. In Fundamentals of Musculoskeletal Pain. (Seattle: International Association for the Study of Pain), pp. 347-366.

Atkinson G. and Nevill A.M. (1998). Statistical methods for assessing measurement error (reliability) in variables relevant to sports medicine. Sports Med 26, 217-238.

Atkinson J.H., Slater M.A., Williams R.A., Zisook S., Patterson T.L., Grant I., Wahlgren D.R., Abramson I., Garfin S.R. (1998). A placebo-controlled randomized clinical trial of nortriptyline for chronic low back pain. Pain 76, 287-296.

Bakhtiary A.H., Safavi-Farokhi Z., Aminian-Far A. (2007). Influence of vibration on delayed onset of muscle soreness following eccentric exercise. Br J Sports Med 41, 145-148. 
Bijur P.E., Latimer C.T., Gallagher E.J. (2003). Validation of a verbally administered numerical rating scale of acute pain for use in the emergency department. Acad Emerg Med 10, 390392.

Bland J.M. and Altman D.G. (1999). Measuring agreement in method comparison studies. Stat Methods Med Res 8, 135-160.

Boivie J. (2003). Central pain and the role of quantitative sensory testing (QST) in research and diagnosis. Eur J Pain 7, 339-343.

Boivie J., Leijon G., Johansson I. (1989). Central post-stroke pain--a study of the mechanisms through analyses of the sensory abnormalities. Pain 37, 173-185.

Boivie J.r., Hansson P., Lindblom U. (1994). Touch, temperature, and pain in health and disease : mechanisms and assessments : a Wenner-Gren Center International Symposium. (Seattle: IASP Press).

Buchanan H.M. and Midgley J.A. (1987). Evaluation of Pain Threshold Using a Simple Pressure Algometer. Clin Rheumatol 6, 510-517.

Burke R.E. (2007). Sir Charles Sherrington's the integrative action of the nervous system: a centenary appreciation. Brain 130, 887-894.

Cariga P., Catley M., Mathias C.J., Ellaway P.H. (2001). Characteristics of habituation of the sympathetic skin response to repeated electrical stimuli in man. Clin Neurophysiol 112, 1875-1880.

Chesterton L.S., Sim J., Wright C.C., Foster N.E. (2007). Interrater reliability of algometry in measuring pressure pain thresholds in healthy humans, using multiple raters. Clin J Pain 23, 760-766.

Chien A., Eliav E., Sterling M. (2008). Whiplash (grade II) and cervical radiculopathy share a similar sensory presentation: an investigation using quantitative sensory testing. Clin $J$ Pain 24, 595-603.

Chung S.C., Um B.Y., Kim H.S. (1992). Evaluation of pressure pain threshold in head and neck muscles by electronic algometer: intrarater and interrater reliability. Cranio 10, 28-34.

Dagtekin O., König E., Gerbershagen H.J., Marcus H., Sabatowski R., Petzke F. (2007). Messung der Druckschmerzempfindlichkeit. Der Schmerz 21, 439-444.

Degenhardt B.F. (2009). New horizons for research and education in osteopathic manipulative medicine. J Am Osteopath Assoc 109, 76-78.

Degenhardt B.F., Johnson J.C., Snider K.T., Snider E.J. (2010). Maintenance and improvement of interobserver reliability of osteopathic palpatory tests over a 4-month period. $J \mathrm{Am}$ Osteopath Assoc 110, 579-586.

Degenhardt B.F., Snider K.T., Snider E.J., Johnson J.C. (2005). Interobserver reliability of osteopathic palpatory diagnostic tests of the lumbar spine: improvements from consensus training. J Am Osteopath Assoc 105, 465-473.

Ekblom A. and Hansson P. (1988). Pain intensity measurements in patients with acute pain receiving afferent stimulation. J Neurol Neurosurg Psychiatry 51, 481-486.

Fingleton C.P., Dempsey L., Smart K., Doody C.M. (2014). Intraexaminer and interexaminer reliability of manual palpation and pressure algometry of the lower limb nerves in asymptomatic subjects. J Manipulative Physiol Ther 37, 97-104.

Finocchietti S., Andresen T., Arendt-Nielsen L., Graven-Nielsen T. (2012). Pain evoked by pressure stimulation on the tibia bone - influence of probe diameter on tissue stress and strain. Eur J Pain 16, 534-542. 
Fleiss J. (1986). The design and analysis of clinical experiments. (New York: John Wiley and Sons).

Gebhart G.F. (2004). Descending modulation of pain. Neurosci Biobehav Rev 27, 729-737.

Goddard G., Karibe H., McNeill C. (2004). Reproducibility of visual analog scale (VAS) pain scores to mechanical pressure. Cranio 22, 250-256.

Gracely R.H., Dubner R., McGrath P.A. (1979). Narcotic analgesia: fentanyl reduces the intensity but not the unpleasantness of painful tooth pulp sensations. Science 203, 12611263.

Gracely R.H. and Kwilosz D.M. (1988). The Descriptor Differential Scale: applying psychophysical principles to clinical pain assessment. Pain 35, 279-288.

Gracely R.H., McGrath P., Dubner R. (1978). Validity and sensitivity of ratio scales of sensory and affective verbal pain descriptors: manipulation of affect by diazepam. Pain 5, 19-29.

Graven-Nielsen T. and Arendt-Nielsen L. (2010). Assessment of mechanisms in localized and widespread musculoskeletal pain. Nat Rev Rheumatol 6, 599-606.

Graven-Nielsen T., Arendt-Nielsen L., Mense S. (2008). Fundamentals of Musculosceletal Pain. (Seattle: International Association for the Study of Pain).

Graven-Nielsen T., Mense S., Arendt-Nielsen L. (2004). Painful and non-painful pressure sensations from human skeletal muscle. Exp Brain Res 159, 273-283.

Greenspan J.D., Ohara S., Sarlani E., Lenz F.A. (2004). Allodynia in patients with post-stroke central pain (CPSP) studied by statistical quantitative sensory testing within individuals. Pain 109, 357-366.

Guyot J.P., Sigrist A., Pelizzone M., Kos M.I. (2011). Adaptation to steady-state electrical stimulation of the vestibular system in humans. Ann Otol Rhinol Laryngol 120, 143-149.

Halma K.D., Degenhardt B.F., Snider K.T., Johnson J.C., Flaim M.S., Bradshaw D. (2008). Intraobserver reliability of cranial strain patterns as evaluated by osteopathic physicians: a pilot study. J Am Osteopath Assoc 108, 493-502.

Hansson P. and Ekblom A. (1986). Influence of stimulus frequency and probe size on vibrationinduced alleviation of acute orofacial pain. Appl Neurophysiol 49, 155-165.

Harte S.E., Mitra M., Ichesco E.A., Halvorson M.E., Clauw D.J., Shih A.J., Kruger G.H. (2013). Development and validation of a pressure-type automated quantitative sensory testing system for point-of-care pain assessment. Med Biol Eng Comput.

Hassler R. (1976). [Interaction between the systems involved in fast pain perception and in slow, persistent pain (author's transl)]. Langenbecks Arch Chir 342, 47-61.

Hogeweg J.A., Langereis M.J., Bernards A.T., Faber J.A., Helders P.J. (1992). Algometry. Measuring pain threshold, method and characteristics in healthy subjects. Scand $J$ Rehabil Med 24, 99-103.

Hollins M., Harper D., Maixner W. (2011). Changes in pain from a repetitive thermal stimulus: the roles of adaptation and sensitization. Pain 152, 1583-1590.

Hori J. and Kishi T. (2011). Objective evaluation of somatic sensation for mechanical stimuli by means of cortical dipole layer imaging. Conf Proc IEEE Eng Med Biol Soc 2011, 70217024.

Hurtig I.M., Raak R.I., Kendall S.A., Gerdle B., Wahren L.K. (2001). Quantitative sensory testing in fibromyalgia patients and in healthy subjects: identification of subgroups. Clin J Pain 17, 316-322.

Izumi M., Petersen K.K., Arendt-Nielsen L., Graven-Nielsen T. (2013). Different patterns of pain referral and regional deep tissue hyperalgesia in experimental human hip pain 
models. Abstract Book of the 8th Congress of the European Federation of IASP Chapters (EFIC), 145.

Jaeger B. and Reeves J.L. (1986). Quantification of changes in myofascial trigger point sensitivity with the pressure algometer following passive stretch. Pain 27, 203-210.

Jensen K., Andersen H.O., Olesen J., Lindblom U. (1986). Pressure-pain threshold in human temporal region. Evaluation of a new pressure algometer. Pain 25, 313-323.

Jespersen A., Dreyer L., Kendall S., Graven-Nielsen T., Arendt-Nielsen L., Bliddal H., Danneskiold-Samsoe B. (2007). Computerized cuff pressure algometry: A new method to assess deep-tissue hypersensitivity in fibromyalgia. Pain 131, 57-62.

Johnson T.W. and Watson P.J. (1997). An inexpensive, self-assembly pressure algometer. Anaesthesia 52, 1070-1072.

Jones D.H., Kilgour R.D., Comtois A.S. (2007). Test-retest reliability of pressure pain threshold measurements of the upper limb and torso in young healthy women. $J$ Pain 8, 650-656.

Kakigi R. and Shibasaki H. (1992). Mechanisms of pain relief by vibration and movement. $J$ Neurol Neurosurg Psychiatry 55, 282-286.

Keele K.D. (1954). Pain-sensitivity tests; the pressure algometer. Lancet 266, 636-639.

Kojo I. and Pertovaara A. (1987). The effects of stimulus area and adaptation temperature on warm and heat pain thresholds in man. Int J Neurosci 32, 875-880.

Koo T.K., Guo J.Y., Brown C.M. (2013). Test-retest reliability, repeatability, and sensitivity of an automated deformation-controlled indentation on pressure pain threshold measurement. J Manipulative Physiol Ther 36, 84-90.

Kosek E., Ekholm J., Nordemar R. (1993). A comparison of pressure pain thresholds in different tissues and body regions. Long-term reliability of pressure algometry in healthy volunteers. Scand J Rehabil Med 25, 117-124.

Kruger G., Harte S.E., Ichesco E., Mitra M., Cheok S.K., Yun X., Clauw D.J., Shih A. (2011). Multimodal Automated Quantitative Sensory Testing System for Pain Research. J Med Device 5, 027530-027530.

Kumazawa T. and Mizumura K. (1977). Thin-fibre receptors responding to mechanical, chemical, and thermal stimulation in the skeletal muscle of the dog. J Physiol 273, 179194.

Marchettini P., Simone D.A., Caputi G., Ochoa J.L. (1996). Pain from excitation of identified muscle nociceptors in humans. Brain Res 740, 109-116.

Melzack R. and Wall P.D. (1996). Pain mechanisms: A new theory (Reprinted from Science, vol 150, pg 971-979, 1965). Pain Forum 5, 3-11.

Mendell L.M. (1966). Physiological properties of unmyelinated fiber projection to the spinal cord. Exp Neurol 16, 316-332.

Mense S. (1981). Sensitization of group IV muscle receptors to bradykinin by 5 hydroxytryptamine and prostaglandin E2. Brain Res 225, 95-105.

Mense S. (1993). Nociception from skeletal muscle in relation to clinical muscle pain. Pain 54, 241-289.

Mense S., Simons D.G., Russell I.J. (2001). Muscle pain : understanding its nature, diagnosis, and treatment. (Philadelphia: Lippincott Williams \& Wilkins).

Miller M.D. and Ferris D.G. (1993). Measurement of subjective phenomena in primary care research: the Visual Analogue Scale. Fam Pract Res J 13, 15-24.

Nie H., Arendt-Nielsen L., Andersen H., Graven-Nielsen T. (2005). Temporal summation of pain evoked by mechanical stimulation in deep and superficial tissue. $J$ Pain 6, 348-355. 
Nie H., Graven-Nielsen T., Arendt-Nielsen L. (2009). Spatial and temporal summation of pain evoked by mechanical pressure stimulation. Eur J Pain 13, 592-599.

Nussbaum E.L. and Downes L. (1998). Reliability of clinical pressure-pain algometric measurements obtained on consecutive days. Phys Ther 78, 160-169.

Ohnhaus E.E. and Adler R. (1975). Methodological problems in the measurement of pain: a comparison between the verbal rating scale and the visual analogue scale. Pain 1, 379384.

Ohrbach R., Crow H., Kamer A. (1998). Examiner expectancy effects in the measurement of pressure pain thresholds. Pain 74, 163-170.

Persson A.L., Brogardh C., Sjolund B.H. (2004). Tender or not tender: test-retest repeatability of pressure pain thresholds in the trapezius and deltoid muscles of healthy women. J Rehabil Med 36, 17-27.

Pette D. and Vrbova G. (1992). Adaptation of mammalian skeletal muscle fibers to chronic electrical stimulation. Rev Physiol Biochem Pharmacol 120, 115-202.

Polianskis R., Graven-Nielsen T., Arendt-Nielsen L. (2001). Computer-controlled pneumatic pressure algometry--a new technique for quantitative sensory testing. Eur J Pain 5, 267277.

Polianskis R., Graven-Nielsen T., Arendt-Nielsen L. (2002a). Pressure-pain function in desensitized and hypersensitized muscle and skin assessed by cuff algometry. J Pain 3, 28-37.

Polianskis R., Graven-Nielsen T., Arendt-Nielsen L. (2002b). Spatial and temporal aspects of deep tissue pain assessed by cuff algometry. Pain 100, 19-26.

Rainwater A.J. and Mcneil D.W. (1991). Reinventing the Algometer - Synopsis of the Literature and Presentation of a Reliable, Inexpensive Model. Behavior Research Methods Instruments \& Computers 23, 486-492.

Reeves J.L., Jaeger B., Graffradford S.B. (1986). Reliability of the Pressure Algometer as a Measure of Myofascial Trigger Point Sensitivity. Pain 24, 313-321.

Roach K.E., Brown M.D., Dunigan K.M., Kusek C.L., Walas M. (1997). Test-retest reliability of patient reports of low back pain. J Orthop Sports Phys Ther 26, 253-259.

Samuelsson M., Leffler A.S., Hansson P. (2005). Dynamic mechanical allodynia: on the relationship between temporo-spatial stimulus parameters and evoked pain in patients with peripheral neuropathy. Pain 115, 264-272.

Schmidt R., Schmelz M., Torebjork H.E., Handwerker H.O. (2000). Mechano-insensitive nociceptors encode pain evoked by tonic pressure to human skin. Neuroscience 98, 793800.

Staud R., Cannon R.C., Mauderli A.P., Robinson M.E., Price D.D., Vierck C.J., Jr. (2003). Temporal summation of pain from mechanical stimulation of muscle tissue in normal controls and subjects with fibromyalgia syndrome. Pain 102, 87-95.

Tenbokum L. and Lavigne G.Algometer with pressure intensification rate adjusting and control capabilities. US Patent 5592947; 1997.

van Wilgen C.P., Konopka K.H., Keizer D., Zwerver J., Dekker R. (2013). Do patients with chronic patellar tendinopathy have an altered somatosensory profile? A Quantitative Sensory Testing (QST) study. Scand J Med Sci Sports 23, 149-155.

Vaughan B., McLaughlin P., Gosling C. (2007). Validity of an electronic pressure algometer. Int J Osteopath Med 10, 24-28. 
Walker I.R. (2011). Reliability in scientific research: improving the dependability of measurements, calculations, equipment, and software. (Cambridge: Cambridge University Press).

Weerakkody N.S., Percival P., Hickey M.W., Morgan D.L., Gregory J.E., Canny B.J., Proske U. (2003). Effects of local pressure and vibration on muscle pain from eccentric exercise and hypertonic saline. Pain 105, 425-435.

Weir J.P. (2005). Quantifying test-retest reliability using the intraclass correlation coefficient and the SEM. J Strength Cond Res 19, 231-240.

Wheeler A.A. and Jacobson B.H. (2013). Effect of whole-body vibration on delayed onset muscular soreness, flexibility, and power. J Strength Cond Res 27, 2527-2532.

Wylde V., Palmer S., Learmonth I.D., Dieppe P. (2011). Test-retest reliability of Quantitative Sensory Testing in knee osteoarthritis and healthy participants. Osteoarthritis Cartilage 19, 655-658.

Xiong S.P., Goonetilleke R.S., Jiang Z.H. (2011). Pressure thresholds of the human foot: measurement reliability and effects of stimulus characteristics. Ergonomics 54, 282-293.

Xiong S.P., Goonetilleke R.S., Witana C.P., Rodrigo W.D.A.S. (2010). An indentation apparatus for evaluating discomfort and pain thresholds in conjunction with mechanical properties of foot tissue in vivo. J Rehabil Res Dev 47, 629-641.

Zaslansky R. and Yarnitsky D. (1998). Clinical applications of quantitative sensory testing (QST). J Neurol Sci 153, 215-238.

Zimkowski M.M., Lindley E.M., Patel V.V., Rentschler M.E. (2011). Design and Evaluation of a Computer-Controlled Pressure Algometer. J Med Devices - Trans ASME 5, 03100210310026 